\title{
What Kind of Immunity? Federal Officers, State Criminal Law, and the Supremacy Clause
}

\author{
Seth P. Waxman ${ }^{\dagger}$ and Trevor W. Morrison ${ }^{\dagger+}$
}

\section{CONTENTS}

INTRODUCTION

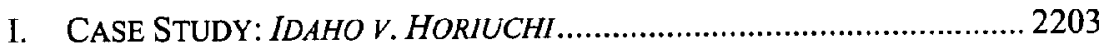

II. BACKGROUND PRINCIPLES .................................................. 2206

A. Officer Liability and Immunity Under Federal Law ................ 2206

1. Sources of Civil and Criminal Liability............................ 2207

2. Qualified Immunity ............................................................ 2209

3. The Fair Warning Requirement...................................... 2211

B. Preemption ....................................................................... 2214

1. General Principles ..................................................... 2215

2. Direct State Regulation of the Federal Government ........... 2218

III. STATE CONSTRAINTS ON FEDERAL LAW ENFORCEMENT ............... 2223

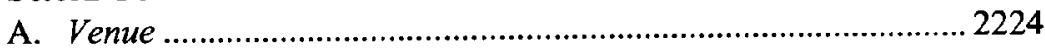

$\dagger$ Partner, Wilmer, Cutler \& Pickering, and Distinguished Visitor from Practice, Georgetown University Law Center. J.D. 1977, Yale Law School. Mr. Waxman served as Solicitor General of the United States between 1997 and 2001. This Article develops ideas suggested in lectures delivered by Mr. Waxman in January 2002 at the University of Kansas School of Law and in May 2002 at the Yale Law School. Mr. Morrison assisted in the preparation of those lectures. The text of the Kansas lecture is published as Seth P. Waxman, Federalism, Low Enforcement, and the Supremacy Clause: The Strange Case of Ruby Ridge, 51 U. KAN. L. REV. 141 (2002). Mr. Waxman presented oral argument on behalf of the United States in two of the principal cases discussed in this Article, Idaho v. Horiuchi, 253 F.3d 359 (9th Cir.) (en banc), vacated as moot, 266 F.3d 979 (9th Cir. 2001), and United States v. Lanier, 520 U.S. 259 (1997).

if Assistant Professor of Law Designate, Cornell Law School. J.D. 1998, Columbia Law School. For helpful comments, the authors thank Michael Dorf, Ted Eisenberg, Vicki Jackson, Gary Lawson, Dan Markel, Bill Marshall, Jay Wexler, and Emie Young. Jon Michaels of The Yale Law Journal provided superb editorial guidance. The opinions expressed in this Article are those of the authors alone. 
B. State Criminal Law and Supremacy Clause Immunity ..............2230

1. Doctrinal Foundations of Supremacy Clause Immunity .....2232

2. Competing Visions of Supremacy Clause Immunity............2237

3. Equating Supremacy Clause Immunity with

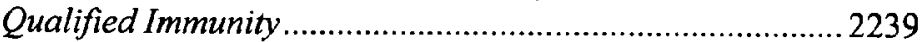

C. State Civil Law ....................................................................... 2242

D. State Rights of Action To Enforce the Constitution:

"Converse-1983"

IV. AN OBJECTION: SEPARATION OF POWERS AS A SAFEGUARD OF FEDERALISM

V. SUPREMACy Clause IMmUNITY AND

CONGRESSIONAL CHOICE. 2252

VI. The Supremacy Clause And National Power 2255

CONCLUSION 2258 


\section{INTRODUCTION}

When, if ever, may a State prosecute a federal officer for allegedly criminal conduct undertaken in discharge of his federal duties? The question goes to the heart of the division of sovereignty embodied in "Our Federalism." Federalism has played a central role in an array of constitutional law developments over the last decade, but there is little case law ${ }^{1}$ and virtually no scholarly commentary ${ }^{2}$ addressing the question posed here. This segment of the long border between national power and state authority is poorly demarcated and irregularly patrolled.

Should that matter? We think the answer is yes, on two counts. First, as a jurisprudential matter the issue is compelling. Unlike most federalism questions arising under constitutional provisions like the Commerce Clause, the Spending Clause, the Eleventh Amendment, or the Fourteenth Amendment, the question of when state criminal processes may be applied against federal law enforcement officers presents an unmediated juxtaposition of the two opposing headlands of the federalism dialectic: the Supremacy Clause and the Tenth Amendment.

Second, the question is far from hypothetical. Indeed, it was recently the focus of controversial, convoluted, and ultimately unresolved litigation that arose out of the August 1992 standoff between the FBI and white separatists at Ruby Ridge, Idaho. ${ }^{3}$ In the course of that standoff, FBI sniper Lon Horiuchi fired at an armed separatist and accidentally killed an unarmed accomplice as she held her infant in her arms. Agent Horiuchi was prosecuted for the shooting, not by the national government that had deployed him, but by a locally elected district attorney. The decision to pursue state criminal charges against a federal agent for actions taken in the course of discharging his official duties raises difficult questions of public policy and law going to the core of our constitutional system. Those questions deserve much more careful and rigorous treatment than they have thus far been given. This Article provides a start.

To appreciate the resonance of the issue, we must first locate it within the broader context of federalism as a central component of American

1. The leading case is In re Neagle. 135 U.S. 1 (1890). But as we discuss in more detail below, Neagle, which stands virtually alone in the Supreme Court's jurisprudence on this issue, raises at least as many questions as it answers.

2. We are aware of only two works giving direct attention to the issue, one seventy-five years old and the other principally concerned with enforcing environmental law. See Susan L. Smith, Shields for the King's Men: Official Immunity and Other Obstacles to Effective Prosecution of Federal Officials for Environmental Crimes, 16 CoLUM. J. ENVTL. L. 1 (1991); John S. Strayhorn, Jr., The Immunity of Federal Officers from State Prosecutions, 6 N.C. L. REV. 123 (1928).

3. See Idaho v. Horiuchi, 215 F.3d 986 (9th Cir. 2000), rev'd en banc, 253 F.3d 359 (9th Cir.), vacated as moot, 266 F.3d 979 (9th Cir. 2001). 
government. "Federalism" refers, of course, to the principle that governmental authority and prerogative should not vest in a single sovereign but rather should be dispersed across all levels of government. ${ }^{4}$ The instantiation of this principle in the Constitution- "split[ting] the atom of sovereignty," as Justice Kennedy put it - is perhaps the most innovative contribution our Founding Fathers made to the principles of democratic governance. And although the Supreme Court has located principles of federalism in many parts of the Constitution, ${ }^{6}$ the provisions that most directly express the principle are the Supremacy Clause $^{7}$ and the Tenth

4. The Federalist contains many of the best articulations of this principle and the purposes it serves:

Power being almost always the rival of power, the general government will at all times stand ready to check the usurpations of the state governments, and those will have the same disposition towards the general government.... If [the people's] rights are invaded by either, they can make use of the other as the instrument of redress.

THE FEDERALIST No. 28, at 181 (Alexander Hamilton) (Clinton Rossiter ed., 1961). The Federalist also described this principle in tandem with a related idea of divided sovereignty, the separation of powers:

In the compound republic of America, the power surrendered by the people is first divided between two distinct governments, and then the portion allotted to each subdivided among distinct and separate departments. Hence a double security arises to the rights of the people. The different governments will control each other, at the same time that each will be controlled by itself.

THE FEDERALIST No. 51, supra, at 323 (James Madison). See generally IACK N. Rakove, ORIGINAL MEANINGS: POLITICS AND IDEAS IN THE MAKING UF THE CONSTITUTION 188-201 (1996) (discussing early Federalists' views).

5. U.S. Term Limits, Inc. v. Thornton, 514 U.S. 779, 838 (1995) (Kennedy, J., concurring).

6. In the last decade alone, the Supreme Court has pursued a dramatic rearticulation of federalist principles in cases arising under the Commerce Clause, the Eleventh Amendment, and the Fourteenth Amendment. See, e.g., Bd. of Trs. of the Univ. of Ala. v. Garrett, 531 U.S. 356 (2001) (Eleventh and Fourteenth Amendments); United States v. Morrison, 529 U.S. 598 (2000) (Commerce Clause and Fourteenth Amendment); Kimel v. Fla. Bd. of Regents, 528 U.S. 62 (2000) (Eleventh and Fourteenth Amendments); Coll. Sav. Bank v. Fla. Prepaid Postsecondary Educ. Expense Bd., 527 U.S. 666 (1999) (Eleventh Amendment); Fla. Prepaid Postsecondary Educ. Expense Bd. v. Coll. Sav. Bank, 527 U.S. 627 (1999) (Eleventh Amendment); Seminole Tribe v. Florida, 517 U.S. 44 (1996) (Eleventh Amendment); United States v. Lopez, 514 U.S. 549 (1995) (Commerce Clause). The Court has also decided cases according to federalist principles not found in any particular constitutional provision, but apparently implicit in the "constitutional framework." Fed. Mar. Comm'n v. S.C. State Ports Auth., 535 U.S. 743 (2002). In Federal Maritime Commission, the Court held that States are immune from privately initiated administrative proceedings before the Federal Maritime Commission. The Court described this immunity as an aspect of the "[d]ual sovereignty [that] is a defining feature of our Nation's constitutional blueprint." Id. at 751. The Court also appears to have conceded, however, that this immunity is not found in any particular constitutional provision. See id. at 754 ("[T] he sovereign immunity enjoyed by the States extends beyond the literal text of the Eleventh Amendment."); $i d$. at $767 \mathrm{n} .18$ ("The principle of state sovereign immunity enshrined in our constitutional framework ... is not rooted in the Tenth Amendment."); see also Alden v. Maine, 527 U.S. 706, 730 (1999) (holding that sovereign immunity shields States from private suits in state courts pursuant to federal causes of action, and rejecting the objection that such immunity is not found in any particular constitutional provision as "engag[ing] in the type of ahistorical literalism we have rejected in interpreting the scope of the States' sovereign immunity since the discredited decision in Chisholm [v. Georgia, 2 U.S. (2 Dall.) 419 (1793)]").

7. U.S. ConST. art. VI ("This Constitution, and the Laws of the United States which shall be made in Pursuance thereof. . . shall be the supreme Law of the Land."). 
Amendment. ${ }^{8}$ Together, these provisions describe a straightforward, generally applicable rule: Where Congress and the President act within the powers expressly afforded them by the Constitution, their laws and acts prevail; in all other respects, power and authority reside with the States, or with the people themselves. ${ }^{9}$

In practice, of course, things rarely divide cleanly into hermetic categories, and these provisions by themselves tell us relatively little about how to balance federal and state power in any particular case. The Tenth Amendment, the Court has explained, "is essentially a tautology.... [It] confirms that the power of the Federal Government is subject to limits that may, in a given instance, reserve power to the States." ${ }^{\circ}$ But the Amendment itself does not identify those instances; rather, it simply "directs us to determine... whether an incident of state sovereignty is protected by a limitation on an Article I power."11 Similarly, although the Supremacy Clause makes federal law supreme within its proper compass, the Clause by itself gives no instructions for calibrating that compass. ${ }^{12}$ Somewhat ironically, then, while the Supremacy Clause and Tenth Amendment together describe the general terms of the federalist balance more directly than any other constitutional provisions, they nonetheless give little specific guidance on how to strike that balance in particular cases. ${ }^{13}$ Many federalism issues thus defy easy textual resolution and must instead be approached more creatively, with sensitivity to the underlying constitutional values at stake.

8. Id. amend. X ("The powers not delegated to the United States by the Constitution, nor prohibited by it to the States, are reserved to the States respectively, or to the people.").

9. This principle is consistent with Garcia v. San Antonio Metropolitan Transit Authority, which recognized that the federal government generally has plenary authority to act within the boundaries of its enumerated powers, and described the federalist limits on that authority as merely structural. See 469 U.S. 528, 550 (1985) ("[T] he principal means chosen by the Framers to ensure the role of the States in the federal system lies in the structure of the Federal Government itself."). We say the principle is "generally applicable" because the Court's "commandeering" precedents suggest that the Tenth Amendment contains some independent constraints on federal power that do not simply mirror the boundaries of an enumerated power. See, e.g., Printz v. United States, 521 U.S. 898, 918-19 (1997); New York v. United States, 505 U.S. 144, 156-57 (1992).

10. New York, 505 U.S. at 156-57.

11. Id. at 157 .

12. For example, in Printz, the Court remarked:

The Supremacy Clause, however, makes "Law of the Land" only "Laws of the United States which shall be made in Pursuance [of the Constitution]," Art. VI, cl. 2, so the Supremacy Clause merely brings us back to the question discussed earlier, whether laws conscripting state officers violate state sovereignty and are thus not in accord with the Constitution.

521 U.S. at $924-25$ (alteration in original).

13. Indeed, for much of our constitutional history, the Tenth Amendment itself was thought to do little more than prohibit the federal government from telling a State where it could locate its capital. See Coyle v. Smith, 221 U.S. 559, 565 (1911). 
Our system of government is replete with zones of overlapping state and federal authority, and questions often arise in those areas about how best to reconcile the competing sovereignties. Among the most difficult is the question posed at the opening of this Article: whether, and to what extent, state criminal law can constrain federal officers in the discharge of their federal duties. The States wield the general police power, ${ }^{14}$ but in some areas their criminal jurisdiction is concurrent with that of the federal government. And in areas legitimately subject to federal criminal jurisdiction, the Supremacy Clause provides that federal law trumps state law with which it conflicts. But what happens when a federal officer exceeds the boundaries of his federal authority and treads upon an area of state concern? In what circumstances may States assign criminal consequences to such transgressions? And assuming a State may not impose criminal penalties on a federal officer for conduct that is concededly within his federal authority, who determines whether the officer has exceeded the bounds of that authority in any particular case?

Early proponents of the Constitution suggested that federalism is a means for the state and federal governments to "control each other," 15 and from such statements one might conclude that subjecting federal officers to the constraints of state criminal law is simply an instance of federalism at work. But does that follow? Clearly, federal officers have no warrant to discharge their duties in a manner that violates the federal Constitution. But is the application of state criminal law an appropriate-indeed, a permissible-method of enforcing the Constitution's requirements? To what extent may States craft remedies against the overreaching of federal officers that exceed or otherwise conflict with remedies available under federal law?

We propose to address these questions by using the Ruby Ridge case, Idaho v. Horiuchi, ${ }^{16}$ as a point of reference. The case turned on Agent Horiuchi's assertion of "Supremacy Clause immunity" from Idaho's attempt to prosecute him for conduct undertaken in discharge of his federal duties. ${ }^{17}$ The theoretical existence of such immunity has been clear for over a century, ${ }^{18}$ but its precise scope, doctrinal basis, and relation to other forms of officer immunity remain somewhat obscure.

Especially given the paucity of case law and scholarly commentary on Supremacy Clause immunity, it is difficult to say how these issues would be resolved if subjected to definitive judicial treatment today. We offer no

14. See United States v. Lopez, 514 U.S. 549, 564 (1995) (recognizing "criminal law enforcement" as an area "where States historically have been sovereign").

15. THE FEDERALIST NO. 51, supra note 4, at 323 (James Madison).

16. 215 F.3d 986 (9th Cir. 2000), rev'd en banc, 253 F.3d 359 (9th Cir.), vacated as moot, 266 F.3d 979 (9th Cir. 2001).

17. Horiuchi, 215 F.3d at 992.

18. See In re Neagle, 135 U.S. 1 (1890). 
predictions. Our substantive view, however, is that although the constitutional principles of federalism and state sovereignty enshrined in the Tenth Amendment certainly inform the proper analysis, they do not ensure any particular role for the States in policing the conduct of federal officers. To the extent States have any role in this area, it is the product not of constitutional guarantee but rather the lack of congressional prohibition or intolerable conflict between state and federal interests. And in areas in which Congress has not explicitly addressed the extent to which federal officers may be subject to the constraints of state law, two guideposts direct the analysis: the federal government's interest in ensuring that States do not interfere with federal policy and prerogatives by criminalizing the execution of federal law, and federal officers' due process right to fair warning before they are subjected to criminal sanction for conduct they reasonably believed to be within their authority.

This Article proceeds in six Parts. In Part I, we briefly describe the facts and proceedings in Idaho v. Horiuchi, our paradigmatic case. Horizchi pitted a State's plenary police power directly against the federal interest in ensuring the effective implementation of federal policy. It thus provides a useful context for considering the issues raised in this Article. Part II discusses two different sets of background principles bearing on Supremacy Clause immunity. We first survey mechanisms for holding law enforcement officers civilly and criminally liable under federal law, as well as the immunities available to officers sued or prosecuted under those laws. We focus in particular on the doctrine of qualified immunity in the civil context, and on the due process requirement of fair warning in the criminal context. Because Supremacy Clause immunity is so little developed, our discussion of officer immunity in these other contexts provides a useful set of analogies. This analogical inquiry also highlights an important distinction between federally recognized officer immunity from federally imposed civil or criminal liability, and federally recognized immunity from state-imposed liability. The latter, of course, raises federalism issues not germane to the former.

To provide a context for thinking about those issues, we also discuss in Part II the Supreme Court's preemption jurisprudence. Preemption principles govern the circumstances in which federal law may displace otherwise applicable state law. Those principles-and especially principles of implied conflict preemption in cases in which a State attempts to regulate the federal government or its agents directly-provide useful guidance for assessing when, and how, Supremacy Clause immunity may restrain the application of state criminal law.

We examine Supremacy Clause immunity directly in Part III. We first consider venue questions raised by state criminal prosecutions of federal officers, and then examine Supremacy Clause immunity as a substantive 
matter. Although the relevant case law is limited, it does establish that an officer's entitlement to immunity is determined by examining the reasonableness of his actions in light of his federal powers and duties alone, irrespective of the requirements of state criminal law. Federal officers are fairly expected to act within the limits of their federal authority, reasonably understood; they are not also obliged separately to ascertain the status of their conduct under state law. Accordingly, we argue that federal officers acting within the scope of their employment should be immune from state prosecution for taking any action that they reasonably believe is necessary and proper to the performance of their federal functions. Properly applied, this standard is effectively coextensive with qualified immunity.

One question arising out of our discussion of Supremacy Clause immunity is whether "Our Federalism" requires federal-state symmetry in matters of intersovereign prosecution and immunity. To address that question, we conclude Part III by considering Akhil Amar's proposal that States enact statutes creating civil rights of action against federal officers who violate the national Constitution. ${ }^{19}$ We think States probably could enact such statutes as a general matter. The real question, however, is whether and to what extent they could depart substantively from the available federal remedies. On that point, we disagree with Amar's suggestion that States could subject federal officers to greater liability than they are subject to in federal causes of action under Bivens $v$. Six Unknown Named Agents of Federal Bureau of Narcotics. ${ }^{20}$ In particular, unless qualified immunity is eliminated (legislatively or judicially) in the Bivens context, we think States could not do so in the kinds of statutes Amar proposes. Any such statute would, we think, be subject to implied conflict preemption on the ground that it conflicts with the federal interest in qualified immunity for federal officers.

In Part IV, we address a potential objection to our general thesis. One might argue that by permitting state criminal law to be displaced whenever it conflicts with an individual federal officer's incorrect, though reasonable, belief that his conduct is authorized by federal law, we put the power to alter the federal-state balance in the hands of every individual federal officer. The Supremacy Clause makes the "Laws of the United States" supreme, not the individual judgments of federal officers. Thus, the argument might go, to preempt state criminal law the federal government should have to speak clearly through the legislative process. Though forceful, this argument imposes untenable restrictions on the exercise of

19. See Akhil Reed Amar, Of Sovereignty and Federalism, 96 YALE L.J. 1425, 1512-19 (1987) [hereinafter Amar, Sovereignty and Federalism]; Akhil Reed Amar, Using State Law To Protect Federal Constitutional Rights: Some Questions and Answers About Converse-1983, $64 \mathrm{U}$. COLO. L. REV. 159 (1993) [hereinafter Amar, Questions and Answers].

20. 403 U.S. 388 (1971). 
federal power. The Supreme Court has long recognized that the integrity of federal law depends on its effective execution, and that federal officers must therefore be accorded the discretionary leeway they need to do their jobs effectively. Moreover, Supremacy Clause immunity's intrusion on state criminal law is actually quite modest. The federal interest in ensuring the effective execution of federal law, we conclude, justifies the intrusion.

Cases involving Supremacy Clause immunity generally arise in areas in which Congress has not spoken directly to the question whether federal officers are subject to state criminal law. Thus, the analysis requires drawing inferences from congressional silence and constitutional structure. But to what extent may Congress alter the federal-state balance in this area? We address this question in Part V. We conclude that, within certain outer boundaries, the precise scope of Supremacy Clause immunity is ultimately more a matter of congressional discretion than constitutional command.

Finally, in Part VI, we view Supremacy Clause immunity through a wider lens. We connect our understanding of this immunity to more general questions about the allocation of federal and state power in a time of heightened sensitivity to problems of a distinctly national, and even international, cast. Just as the precise scope of Supremacy Clause immunity is congressionally alterable, so too should Congress be given wide leeway in fashioning cooperative federal responses to a wide range of problems of truly national concern. In both cases, the point is to resist the recent trend toward discovering new and increasingly aggressive per se constitutional limitations on federal power, and instead to recognize that the elected branches of the federal government are often in a better position to strike the federalist balance.

\section{CASE STUDY: IDAHO V. HORIUCHI}

For over a year, United States marshals had attempted, without success, to arrest Randall Weaver for his refusal to answer gun-trafficking charges. ${ }^{21}$ Weaver was a separatist; he despised the federal government; and he had made it clear that he would not surrender. ${ }^{22}$ Instead, he, his wife Vicki, and their children stayed on their remote property near Ruby Ridge, heavily armed and avowedly prepared to use force to repel anyone who approached them. On August 21, 1992, several marshals were scouting the area near the Weaver property when they were confronted by Weaver, his son, and a

21. This summary draws on the Ninth Circuit's description of the facts in its panel and en banc opinions in the case, and also on the factual background contained in the amicus curiae brief filed in the Ninth Circuit by the United States. See Brief of the United States as Amicus Curiae in Support of Appellee, Idaho v. Horiuchi, 215 F.3d 986 (9th Cir. 2000) (No. CR-98-30149).

22. See. e.g., George Lardner, Jr. \& Richard Leiby, Standoff at Ruby Ridge, WASH. POST, Sept. 3, 1995, at Al (describing "Weaver's anti-government views" as "well-known"). 
family friend named Kevin Harris. A firefight erupted, leaving a deputy marshal and Weaver's son both dead.

In response, FBI Special Agent Lon Horiuchi and other members of the FBI's elite Hostage Rescue Team were deployed to Ruby Ridge. Upon their arrival, Horiuchi and the other team members were advised that their mission would be extremely dangerous. They were told that Weaver was wanted on a federal weapons charge and had evaded arrest for over a year; that Weaver and Harris were suspects in the deputy marshal's shooting and were believed to have retreated into the Weavers' cabin where they could use the Weaver children as shields; that the property contained caches of weapons; that Weaver was a Special Forces veteran; and that sympathetic neighbors were reportedly gathering to support the besieged family. Horiuchi and the rest of his team were also advised of special rules of engagement developed by the FBI for the operation. The rules provided that deadly force could be used against any adult male with a weapon in the vicinity of the Weaver cabin, provided a shot could be taken without endangering any of the children in the cabin.

Horiuchi, a trained sniper, was deployed about 200 yards from the Weaver cabin. When an FBI helicopter approached to conduct surveillance, Weaver, Harris, and Weaver's teenage daughter ran from the cabin, armed with rifles. Weaver began to point his rifle to the sky, appearing to aim at the helicopter. Horiuchi responded by firing a shot, striking Weaver in the shoulder. Wounded, Weaver and his companions retreated to the cabin. But before Harris, the last armed male, disappeared inside, Horiuchi aimed at him and shot. Unbeknownst to Horiuchi, Vicki Weaver was standing behind the opened cabin door, holding her infant child in her arms. The bullet went through the outer edge of the door, struck and passed through Vicki Weaver's skull, and ultimately hit Harris. Mrs. Weaver died instantly.

The events of that day - and especially the shot that killed Vicki Weaver-spawned a number of federal investigations. ${ }^{23}$ All of the reports were highly critical of the FBI's conduct. But with respect to Agent Horiuchi, the Attorney General concluded that federal criminal charges were unwarranted. As discussed below, ${ }^{24} 18$ U.S.C. $\S 242$ proscribes the "willful" deprivation of federal constitutional or statutory rights by government actors, and the Justice Department concluded that the facts did not support a finding that Horiuchi had willfully used unreasonable force when firing the shot that killed Vicki Weaver.

23. See, e.g., Idaho v. Horiuchi, 253 F.3d 359, 363-64 \& n.5 (9th Cir.) (en banc), vacated as moot, 266 F.3d 979 (9th Cir. 2001) (discussing the investigation and report by the Justice Department's Office of Professional Responsibility); The Federal Raid on Ruby Ridge, ID: Hearings Before the Subcomm. on Terrorism, Technology, and Government Information of the Senate Comm. on the Judiciary, 104th Cong. 1105-08 (1995) (discussing the Ruby Ridge shootout on August 21, 1992).

24. See infra note 39 and accompanying text. 
Things proceeded differently in Idaho. Five days after the Justice Department announced it would not prosecute Agent Horiuchi, the local prosecutor charged him with involuntary manslaughter in the death of Vicki Weaver. The criminal complaint did not allege that Horiuchi had acted with malice; instead, it alleged that he had been reckless and negligent in firing through the front door of the Weaver cabin without determining whether anyone was behind it. Horiuchi removed the case to federal court ${ }^{25}$ and then moved to dismiss the prosecution on the ground that he had acted properly in the discharge of his duties as a federal law enforcement officer.

The district court granted Horiuchi's motion and a divided appeals panel affirmed, applying a rather lenient version of the test, which we discuss below, for determining whether a federal officer is immune from state criminal prosecution. The court required only that the act in question be within the general scope of the officer's authority, and that the officer have honestly and reasonably believed that the act was necessary and proper under the circumstances. ${ }^{26}$ The key inquiry in Horiuchi's case concerned the reasonableness of his belief that shooting Kevin Harris was necessary and proper in the circumstances. The majority held that Horiuchi satisfied that standard. Judge Kozinski wrote an angry dissent, contending that the facts, which he described as "largely not in dispute," impeached that conclusion. ${ }^{27}$ The Ninth Circuit then elected to rehear the case in an en banc panel of eleven judges. ${ }^{28}$ By a vote of $6-5$, the court reversed the district court's dismissal. Judge Kozinski wrote the majority opinion. Having previously characterized the facts as largely undisputed, he now reversed on the ground that too many facts were in dispute. ${ }^{29}$

The case did not end there. In an extraordinary step, the Ninth Circuit invited briefing on whether the case should be reheard yet again, this time before the court's entire complement of more than twenty active judges. But instead of responding, Idaho dropped the charges altogether. The court responded by vacating the en banc opinion, the panel opinion, and the opinion of the district court. ${ }^{30}$ Idaho $v$. Horiuchi became a nullity. After years of protracted litigation addressing the extent to which States may use

25. Under 28 U.S.C. $\$ 1442(a)(1)$ (2000), federal officers may remove state civil and criminal actions filed against them for acts committed under color of their office. For a discussion of this statute, see infra notes 144-146 and accompanying text.

26. See Horiuchi, 215 F.3d at 993.

27. See id. at 997-98 (Kozinski, J., dissenting).

28. The lineup of counsel at oral argument was bewildering. No one from Idaho appeared for the State, which was represented by a plaintiffs' attorney from Venice Beach, California, and former United States Attorney General Ramsey Clark. Agent Horiuchi (accustomed, of course, to siding with the prosecution) was represented by a criminal defense lawyer. And the United States, appearing as amicus curiae in support of the alleged criminal, was represented by the Solicitor General in a rare appearance outside the Supreme Court.

29. See Idaho v. Horiuchi, 253 F.3d 359, 374 (9th Cir.) (en banc), vacated as moot, 266 F.3d 979 (9th Cir. 2001).

30. Horiuchi, 266 F.3d at 979. 
their criminal laws to discipline the conduct of federal law enforcement officers, the case ultimately stood for nothing at all.

Its rather anticlimactic ending notwithstanding, the facts and proceedings in Horiuchi nicely illustrate a number of salient issues. As a threshold matter, in what circumstances may state courts adjudicate criminal charges against federal officers? And on the merits, when and to what extent may state criminal law be brought to bear on a federal officer for conduct taken in furtherance of his federal duties? On one side of these questions rests the State's authority under the Tenth Amendment to enforce its own criminal laws within its territory. On the other side stands the Supremacy Clause.

\section{BACKGROUND PRINCIPLES}

We cannot fully grasp the issues at work in cases like Horiuchi, let alone arrive at a more general theory of federal officer immunity, without first articulating the background principles informing our assessment of the proper federalist balance in areas like this. Two discrete sets of principles stand out. First, the contours of more familiar forms of officer liability and immunity provide us with doctrinal and practical tools for examining the rights and responsibilities of federal officers under state law. To that end, we discuss the extent to which law enforcement officers can claim immunity from federal civil or criminal liability for their official acts. Second, having discussed officer immunity while momentarily tabling issues of federalism, we then add that missing ingredient by considering principles of preemption jurisprudence. Preemption provides a lens through which we can see how officer immunity might operate in a dual-sovereign context. A successful invocation of immunity by a defendant such as Agent Horiuchi amounts to the federal displacement of otherwise applicable state criminal law. Preemption doctrine governs the mechanics of such displacement in a range of other contexts and is therefore vitally important in framing our discussion here.

\section{A. Officer Liability and Immunity Under Federal Law}

We here consider sources of civil and criminal officer liability under federal law, and the availability of immunity from actions seeking to impose such liability. On the immunity side, we discuss both officers' statutorily based qualified immunity from civil damages actions and their constitutionally grounded right-shared with all criminal defendants--to fair warning before being held criminally responsible for their actions. These forms of immunity, though uncomplicated by the federalism issues 
implicated in Supremacy Clause immunity, provide useful background analogues for the discussion that follows in Part III.

\section{Sources of Civil and Criminal Liability}

The principal federal constraints on law enforcement activity are quite familiar. ${ }^{31}$ First, it is clear that federal law can and does bind the conduct of federal officers. As the source of those officers' authority, federal law-including the Constitution-naturally limits it as well. Second, the power of federal law to constrain the actions of state officials is also well recognized. Although the Supreme Court's recent Tenth Amendment cases have identified limits on the power of the federal government to "commandeer" state officials to assist in the enforcement of federal law, ${ }^{32}$ it remains clear that state officials are themselves subject to and bound by federal law. ${ }^{33}$ The proposition is hardly novel. Indeed, it is one of the few things directly confirmed by the Supremacy Clause itself: Provided the federal law at issue is a proper exercise of federal power, it binds state actors and preempts any state law to the contrary. ${ }^{34}$ The principle is confirmed by other parts of the Constitution as well: The Reconstruction Amendments, for example - and in particular their grants of enforcement power to Congress ${ }^{35}$ - are premised on federal supremacy as a matter of both constitutional theory and practical necessity. In light of this supremacy principle, the key question in determining the extent of federal constraints on the States and state officers is often not whether the federal government can impose such constraints, but whether it has in fact imposed them.

31. See generally THEODORE EISENBERG, CIVIL RIGHTS LEGISLATION: CASES AND Materials (2d ed. 1987); PETER W. LOW \& JOHN C. JEFFries, JR., Civil RightS ACTIONS: SECTION 1983 AND RELATED STATUTES (2d ed. 1994).

32. See Printz v. United States, 521 U.S. 898 (1997) (invalidating a provision of the Brady Act requiring local officials to conduct background checks on prospective handgun buyers); New York v. United States, 505 U.S. 144 (1992) (holding that even when Congress pursues a goal as important as the safe disposal of the nation's hazardous waste, it lacks the constitutional authority to coerce States into enacting legislation to assist that goal). For discussions of the Court's "commandeering" jurisprudence, see, for example, Matthew D. Adler \& Seth F. Kreimer, The New Etiquette of Federalism: New York, Printz, and Yeskey, 1998 SUP. CT. REV. 71; and Vicki C. Jackson, Federalism and the Uses and Limits of Law: Printz and Principle?, 111 HARV. L. REV. 2180 (1998).

33. The point was confirmed recently in Reno $v$. Condon, where a unanimous Court held that although Congress may not compel States to assist in the enforcement of federal laws regulating private conduct, it may regulate state action directly by imposing federal obligations on state actors' primary conduct. 528 U.S. 141 (2000).

34. See McCulloch v. Maryland, 17 U.S. (4 Wheat.) 316, 427 (1819) ("It is of the very essence of supremacy, to remove all obstacles to its action within its own sphere, and so to modify every power vested in subordinate governments, as to exempt its own operations from their own influence.").

35. See U.S. CONST. amend. XIII, § 2; id. amend. XIV, § 5; id. amend. XV, § 2. 
Two federal tools for constraining the conduct of individual law enforcement officers (whether state or federal) stand out as particularly important. The first, of course, is 42 U.S.C. $\$ 1983$, which creates a private right of action against officers who violate rights protected by federal law. ${ }^{36}$ Section 1983 applies only to state and local officers, but the Supreme Court in Bivens v. Six Unknown Named Agents of Federal Bureau of Narcotics ${ }^{37}$ inferred a parallel damages action against federal officers. ${ }^{38}$ The second tool is 18 U.S.C. $\S 242$, which makes it a criminal offense for officers acting under color of federal, state, or local law willfully to deprive individuals of their rights under federal law. ${ }^{39}$ Although there are a variety of other mechanisms for enforcing federal law against government actors, ${ }^{40}$ in the law enforcement area these two tools are arguably the most significant because they expose individual officers to the possibility of personal civil or criminal liability. ${ }^{41}$

36. Section 1983 provides, in pertinent part:

Every person who, under color of any statute, ordinance, regulation, custom, or usage, of any State or Territory or the District of Columbia, subjects, or causes to be subjected, any citizen of the United States or other person within the jurisdiction thereof to the deprivation of any rights, privileges, or immunities secured by the Constitution and laws, shall be liable to the party injured in an action at law, suit in equity, or other proper proceeding for redress ....

42 U.S.C. $\$ 1983(2000)$.

37. 403 U.S. 388 (1971).

38. Section 1983 provides a damages remedy for conduct under color of law that violates either the Constitution or laws of the United States. Bivens does not appear to stretch as far, though its precise scope is not entirely clear. What is clear is that as a remedy for unconstitutional conduct, Bivens is available at least in cases involving the First, Fourth, Fifth, and Eighth Amendments. See Bush v. Lucas, 462 U.S. 367 (1983) (First Amendment); Carlson v. Green, 446 U.S. 14 (1980) (Eighth Amendment); Davis v. Passman, 442 U.S. 228 (1979) (Fifth Amendment); Bivens, 403 U.S. 388 (Fourth Amendment).

39. Section 242 provides, in pertinent part:

Whoever, under color of any law, statute, ordinance, regulation, or custom,

willfully subjects any person in any State, Territory, Commonwealth, Possession, or District to the deprivation of any rights, privileges, or immunities secured or protected by the Constitution or laws of the United States... shall be fined under this title or imprisoned not more than ten years, or both.

18 U.S.C. $\S 242(2000)$. The section provides for more severe punishment if the unlawful conduct causes serious harm such as bodily injury or death. Id.

40. For example, in a range of contexts not confined to criminal law enforcement, the federal government may bring proceedings against States qua States for their failure to comply with various federal laws providing for such enforcement. See, e.g., EEOC v. Wyoming, 460 U.S. 226 (1983). And under the doctrine of Ex parte Young, individuals may also sue state officers in their official capacity to enjoin them from violating federal law. 209 U.S. 123 (1908).

41. The significance of $\S 1983$ in particular is well recognized. It "serves as the basic vehicle for federal court review of alleged state and local violations of federal law." ERWIN CHEMERINSKY, FEDERAL JURISDICTION $\$ 8.1$, at 423 (2d ed. 1994). Some commentators have even gone so far as to announce that "[n]0 . . . statute is more important in contemporary American law." I MarTin A. SCHWARTZ \& JOHN E. KIRKLIN, SECTION 1983 LITIGATION: Claims, DefEnSES, AND FeEs $\S 1.1$, at 4 (2d ed. 1991). 


\section{Qualified Immunity}

Officers subject to potential liability in these areas are shielded to some extent by rules of immunity and fair warning. In the $\S 1983$ and Bivens context, the Supreme Court has fashioned a rule of qualified immunity under which "government officials performing discretionary functions[] generally are shielded from liability for civil damages insofar as their conduct does not violate clearly established statutory or constitutional rights of which a reasonable person would have known., ${ }^{, 2}$ As the Court has explained, qualified immunity accommodates two competing concerns. On one hand, "'action[s] for damages may offer the only realistic avenue for vindication of constitutional guarantees"" when "'government officials abuse their offices." "43 On the other, "damages suits against government officials can entail substantial social costs, including the risk that fear of personal monetary liability and harassing litigation will unduly inhibit officials in the discharge of their duties. ${ }^{, 44}$ Qualified immunity is meant to limit those costs by shielding officers from suit except where their actions were so clearly unconstitutional that a reasonable officer could not have thought otherwise.

It bears emphasizing that qualified immunity does not appear to be constitutionally required. Rather, the Court's cases in this area are premised on the theory that qualified immunity existed at common law, and that Congress did not clearly abolish it in $\S 1983 .^{45}$ Section 1983 certainly implicates issues of federalism, especially when it is invoked to sue state law enforcement officers. But the Court has never suggested that the constitutional balance of federal and state power requires any form of officer immunity in this context. Indeed, it appears that Congress could abolish qualified immunity altogether if it wished-for example, by amending $\S 1983$ to provide for strict liability. ${ }^{46}$

42. Harlow v. Fitzgerald, 457 U.S. 800,818 (1982). Harlow also confirmed that the scope of qualified immunity in Bivens and $\S 1983$ actions is the same. See id. at 809.

43. Anderson v. Creighton, 483 U.S. 635, 638 (1987) (quoting Harlow, 457 U.S. at 814) (alteration in original).

44. Id.; see also Scheuer v. Rhodes, 416 U.S. 232, 240 (1974) (acknowledging the "danger that the threat of ... liability would deter [an officer's] willingness to execute his office with the decisiveness and the judgment required by the public good").

45. See, e.g., Pierson v. Ray, 386 U.S. 547, 554 (1967) (observing that $\S 1983$ 's “legislative record gives no clear indication that Congress meant to abolish wholesale all common-law immunities"); see also Tower v. Glover, 467 U.S. 914, 920 (1984) ("If an official was accorded immunity from tort actions at common law when the Civil Rights Act was enacted in 1871, the Court next considers whether $\S 1983$ 's history or purposes nonetheless counsel against recognizing the same immunity in $\S 1983$ actions."). For an early judicial recognition of discretionary immunity, see Spalding v. Vilas, 161 U.S. 483 (1896).

46. See Richard H. Fallon, JR. ET al., HART AND WechSLER'S The FEDERal Courts AND THE FEDERAL SYSTEM 1167 (4th ed. 1996) [hereinafter HART \& WECHSLER] (questioning whether qualified immunity is constitutionally required). 
This possibility is reflected in the Court's general approach to qualified immunity. If some form of immunity were constitutionally required, it would reflect either a constitutional limitation on the judiciary's ability to enforce a particular legal right or a limitation on the scope of the right itself. But the Court's approach to qualified immunity shows otherwise. As the Court has explained, the threshold question in these cases is "whether the plaintiff has alleged a deprivation of a constitutional right at all. Normally, it is only then that a court should ask whether the right allegedly implicated was clearly established at the time of the events in question." 47 This approach confirms, first, that qualified immunity does not bear on the shape of the constitutional right itself-whether the officer in fact violated the Constitution is analyzed separately from the officer's claim to immunity. Second, because the Court tends not to recognize constitutional rights that it categorically cannot enforce, ${ }^{48}$ the approach also strongly suggests that qualified immunity is not a product of any constitutionally based institutional limitation on the judiciary's remedial power. Indeed, the same constitutional or other right that a plaintiff seeks to vindicate in a $\S 1983$ suit may, in general, also be enforced through Ex parte Young ${ }^{49}$ actions for injunctive relief. In such cases, courts construe and enforce the constitutional provision unmediated by any consideration of qualified immunity. Thus, the availability of qualified immunity from $\S 1983$ liability is simply a matter of statutory interpretation against the backdrop of certain common-law principles. ${ }^{50}$ This point also reflects a recurring theme in this

47. County of Sacramento v. Lewis, 523 U.S. 833, 841 n.5 (1998).

48. See, e.g., City of Boeme v. Flores, 521 U.S. 507 (1997). The Court's occasional conflation of the tests it uses for determining whether a particular constitutional right has been violated with the shape of the underlying constitutional right itself has been the subject of recent criticism. See, e.g., Robert C. Post \& Reva B. Siegel, Equal Protection by Law: Federal Antidiscrimination Legislation After Morrison and Kimel, 110 YALE L.J. 441 (2000). Indeed, one of us has filed briefs on behalf of the United States urging the Court to recognize that certain of its methods of constitutional review-most notably the rational basis test reflect limitations on the judicial power to invalidate legislation on constitutional grounds, not the shape of the underlying constitutional right itself. See, e.g., Brief for the United States at 35-40, Bd, of Trs. of the Univ. of Ala. v. Garrett, 531 U.S. 356 (2001) (No. 99-1240). Four members of the Court appear to agree. See Garrett, 531 U.S. at 382-85 (Breyer, J., joined by Stevens, Souter, and Ginsburg, JJ., dissenting). For present purposes, however, we mean only to observe that the merits/immunity division in the Court's qualified immunity cases tends to confirm that this form of immunity is not derived from the constitutional right itself.

49. 209 U.S. 123 (1908).

50. In the Bivens context, obviously qualified immunity cannot be inferred as a matter of statutory interpretation. The Court has concluded, however, that it would be "untenable to draw a distinction for purposes of immunity law between suits brought against state officials under $\$ 1983$ and suits brought directly under the Constitution against federal officials." Butz v. Economou, 438 U.S. 478, 504 (1978). That conclusion is probably best understood as a matter of federal common law; it, too, could be displaced by specific legislation abolishing qualified immunity for federal officers. We stress, though, that this point does not apply to certain other forms of federal immunity, such as absolute immunity for members of Congress for their legislative acts, see Eastland v. United States Servicemen's Fund, 421 U.S. 491 (1975), and absolute presidential immunity from suits for money damages for his official acts, see Nixon v. 
Article: In areas of overlapping federal and state power, striking the balance is often more a matter of congressional choice than constitutional command.

\section{The Fair Warning Requirement}

The same is not quite true for the "fair warning requirement," the analogous limit on officials' criminal liability under statutes like $\S 242$. The requirement derives from the Due Process Clause ${ }^{51}$ and provides that all criminal statutes - whether directed at government officials in particular or the public more generally - must provide "fair warning ... in language that the common world will understand, of what the law intends to do if a certain line is passed." 52 One manifestation of the requirement is the rule that a court may not apply a "novel construction of a criminal statute to conduct that neither the statute nor any prior judicial decision has fairly disclosed to be within its scope., ${ }^{, 53}$ In theory, this rule functions as a kind of judicial analogue to the Ex Post Facto Clause: ${ }^{54}$ Just as a statute creating a new criminal offense may not be applied retroactively to reach conduct that was lawful at the time, ${ }^{55}$ so too courts may not employ new, unforeseeably expansive interpretations of existing statutes in order to reach past conduct that reasonably appeared lawful at the time. ${ }^{56}$

Though robust as a formal matter, in practical terms the vitality of the fair warning requirement may be on the wane. ${ }^{57}$ But prosecutions of government officers—whether under federal or state law—often raise rather

Fitzgerald, 457 U.S. 731 (1982). Each of these forms of immunity has a constitutional basis: the Speech and Debate Clause for members of Congress; Article II for the President.

51. United States v. Lanier, 520 U.S. 259, 265 (1997) (describing the fair warning requirement as an "application of [the Due Process Clause's] spacious protection of liberty").

52. McBoyle v. United States, 283 U.S. 25, 27 (1931).

53. Lanier, 520 U.S. at 266. For a general discussion of the fair warning requirement as applied to the interpretation of federal criminal statutes, see Trevor W. Morrison, Fair Warning and the Retroactive Judicial Expansion of Federal Criminal Statutes, 74 S. CAL. L. REV. 455 (2001).

54. U.S. CoNST. art. I, $\S 9$, cl. $3 ;$ id. art. I, $\S 10$, cl. 1 .

55. See, e.g., Collins v. Youngblood, 497 U.S. 37, 42 (1990) ("“[A]ny statute which punishes as a crime an act previously committed, which was innocent when done ... is prohibited as $e x$ post facto." (quoting Beazell v. Ohio, 269 U.S. 167, 169-70 (1925))); Calder v. Bull, 3 U.S. (3 Dall.) 386, 390 (1798) (Chase, J.) (describing the categories of impermissible ex post facto laws).

56. See Bouie v. City of Columbia, 378 U.S. 347, 353 (1964) (“' [A]n unforeseeable judicial enlargement of a criminal statute, applied retroactively, operates precisely like an ex post facto law...."). See generally Morrison, supra note 53, at 475-84 (discussing Bowie and other Supreme Court cases developing this rule).

57. See, e.g., Rogers v. Tennessee, 532 U.S. 451 (2001) (finding no fair warning impediment to the retroactive abolition of Tennessee's "year and a day" rule in homicide cases). See generally Harold J. Krent, Should Bouie Be Buoyed?: Judicial Retroactive Lawmaking and the Ex Post Facto Clause, 3 ROGER WILLIAMS U. L. REV. 35 (1997) (describing the Supreme Court's general retreat from Bouie's broad articulation of the rule). 
special issues, and it is worth considering the applicability of fair warning in such cases.

The leading case is United States $v$. Lanier, ${ }^{58}$ which involved the prosecution under $\S 242$ of a former state judge for sexually assaulting several women in his chambers. Unlike typical criminal statutes (but like $\S 1983$ in the civil context), $\S 242$ does not itself define the precise conduct it prohibits. Rather, it criminalizes the "willful" deprivation, under color of law, of an individual's rights under the federal Constitution or laws. The defendant in Lanier raised a fair warning defense to his prosecution, arguing that sexual assault, while a crime under state law, had not previously been clearly defined as a violation of the victim's rights under federal law. Accordingly, the defendant argued, he could not have "willfully" violated such a right, and to declare the right in his case and then apply it against him would be to prosecute him for an offense without fair warning. ${ }^{59}$ The Supreme Court rejected that argument on the ground that common sense, combined with the decisions of various lower federal courts, made it sufficiently clear at the time of the defendant's actions that a judge violates the Constitution when he uses the powers of his office to sexually assault people. ${ }^{60}$

For our purposes, Lanier is significant not for its precise holding but for what it said about the scope of the fair warning requirement. Although it rejected the defendant's particular fair warning defense, the Court actually gave the requirement quite a broad scope. Specifically, the Court likened the fair warning requirement to qualified immunity, concluding that the two are essentially coextensive. As the Court explained:

The fact that one has a civil and the other a criminal law role is of no significance; both serve the same objective, and in effect the qualified immunity test is simply the adaptation of the fair warning standard to give officials (and, ultimately, governments) the same protection from civil liability and its consequences that individuals have traditionally possessed in the face of vague criminal statutes. ${ }^{61}$

In the typical criminal case, equating the fair warning requirement with qualified immunity simply clarifies by way of analogy the degree of notice to which a criminal defendant is entitled. For example, a defendant may have had fair warning of the illegality of his conduct even in the absence of Supreme Court precedent squarely on point, ${ }^{62}$ just as the law may be "clearly established" against a $§ 1983$ defendant in similar circumstances.

58. 520 U.S. 259.

59. See id. at 261-63.

60. Id. at 268-72.

61. Id. at $270-71$.

62. See id. at 268 . 
But the precise content of the analysis will differ. Fair warning in the criminal context is ascertained with respect to the prohibitions contained in the criminal statute at issue; qualified immunity in the civil context is determined with respect to the constitutional or other federal right the defendant is alleged to have violated.

In criminal cases arising under statutes like $\$ 242$, however, the substantive content of the fair warning and qualified immunity analyses are close to identical. In most such cases, the officer is alleged to have violated an individual's constitutional rights. That is, the criminality of his conduct under $\S 242$ is generally ascertained with respect to constitutional norms. So, too, is his exposure to civil liability under $\S 1983$ or Bivens. And because, under Lanier, the officer's qualified immunity is coextensive with his right to fair warning, his ability to avoid civil liability through an assertion of qualified immunity may actually define the extent to which he can avoid criminal penalty under $\S 242$, and vice versa. ${ }^{63}$

Although Lanier's equation of the two immunities in this fashion was not doctrinally necessary, as a policy matter it makes sense. If the defendant's reasonable belief that his conduct was lawful is adequate to immunize him from civil suit, it would be anomalous at best nevertheless to subject him to criminal prosecution for the same conduct. ${ }^{64}$ The prospect of potential criminal liability will chill the officer's exercise of his duties, thus undermining qualified immunity's purpose to insulate against such chill. Indeed, if anything, the gravity of criminal sanctions renders the case for officer immunity in criminal cases even stronger than in civil ones.

Finally, it is worth stressing the limits of fair warning. To be sure, fair warning is constitutionally required. Congress could abolish qualified immunity; it could not constitutionally abolish the fair warning requirement. Equally significant, however, is the fact that the precise scope of an officer's entitlement to fair warning is not constitutionally fixed. Congress could, for example, amend the elements of criminal liability under $\S 242$ and thereby alter the focus of the fair warning inquiry. The Due Process Clause requires fair warning; what warning is fair depends in large measure on the source and content of the criminal sanction at issue.

As we will see later, understanding the import—and limits—of the fair warning requirement is crucial to grappling with Supremacy Clause immunity. Like all potential criminal defendants, federal officers have a due process right to fair warning before being subjected to the constraints of

63. The analyses are not precisely identical: Section 242 is confined to the "willful" deprivation of rights, but $\S 1983$ contains no such limitation. See generally Screws v. United States, 325 U.S. 91 (1945) (discussing the "willful" requirement). Still, in cases where the analysis focuses more on whether the harm to the victim implicates a constitutional right than on whether the defendant willfully caused harm, the content of the fair warning and qualified immunity analyses is likely to be very similar.

64. See Lanier, 520 U.S. at $270-71$. 
state criminal law. In most Supremacy Clause immunity cases, however, the issue is not whether the relevant provisions of state law were sufficiently clear on their own terms to afford adequate warning. In Horiuchi, for example, no one suggested that Idaho's homicide laws did not adequately specify that the reckless killing of another is a criminal offense. Rather, the question in fair warning terms was whether Agent Horiuchi had been given adequate notice that his actions had to comply not only with federal law but also with Idaho law. The question was about what law applied, not what the applicable law provided. As we will explain in more detail below, we think Congress could expressly answer this question either way by passing legislation explicitly subjecting federal officers to, or immunizing them from, state law for acts taken in discharge of their federal duties. ${ }^{65}$ Such an express statement would effectively dictate the outcome of the fair warning analysis in a case like Horiuchi.

In the absence of an express legislated answer, however, the question is what inference to draw from congressional silence. Should the presumption run in favor of applying state criminal law against federal officers, or against it? The fair warning requirement itself is of little use in answering that question, which goes not to the adequacy of notice afforded by a particular legal proscription but to whether the proscription applies at all in a given circumstance. We turn, then, to an area of law directly concerned with such threshold questions.

\section{B. Preemption}

Whether a federally based conception of officer immunity may shield a federal officer from state criminal prosecution is a question about the circumstances in which federal law should be read to displace otherwise applicable state law. Stated at that level of generality, it is comparable to questions of preemption. We therefore address general principles of preemption here, with the aim of developing a set of analytical tools for assessing the federal-state interactions at work in Supremacy Clause immunity.

There are, of course, numerous areas in the law where the regulatory authority of the state and federal governments overlap. ${ }^{66}$ The threshold constitutional question in such cases is often whether the Constitution authorizes the federal government to act in the area at issue. Preemption

65. As we discuss below, see infra Part $\mathrm{V}$, there may be some outer limits on what Congress could do here.

66. See United States v. Locke, 529 U.S. 89, 109 (2000) ("It is fundamental in our federal structure that States have vast residual powers. Those powers, unless constrained or displaced by the existence of federal authority or by proper federal enactments, are often exercised in concurrence with those of the National Government."). 
doctrine does not address that question. Rather, it focuses on the next question: Assuming the federal law or action is constitutional, in what circumstances does it displace state law? This is principally a question of congressional intent. ${ }^{67}$

If the matter being regulated is subject to federal jurisdiction, it is always possible under the Supremacy Clause for Congress to pass legislation expressly displacing all state action in the field. ${ }^{68}$ But even in the absence of such express preemption, the Supreme Court has long held that state laws or actions are also displaced to the extent they "stand[] as an obstacle to the accomplishment and execution of the full purposes and objectives of Congress." 69 This is the basis for the doctrine of implied conflict preemption, the form of preemption most pertinent here. ${ }^{70}$

\section{General Principles}

Implied conflict preemption is informed by two general principles. The first is the presumption against preemption. Where the case arises in an area that is both subject to federal jurisdiction and traditionally regulated by the States, the Court has explained that "we start with the assumption that the historic police powers of the States were not to be superseded ... unless that was the clear and manifest purpose of Congress." "rooted in the concept of federalism" " - specifically, that the constitutional design favors an ongoing role for the States in areas traditionally regulated by them, absent a clear conflict with federal law or a statement from Congress to the contrary.

The effect of the presumption against preemption is to encourage Congress to be clear about the preemptive power of its enactments. In this sense, the presumption is functionally similar to the Court's "clear statement" rules in related areas—rules providing that federal statutes

67. See Medtronic, Inc. v. Lohr, 518 U.S. 470, 485 (1996) ("“[T]he purpose of Congress is the ultimate touchstone' in every pre-emption case." (quoting Retail Clerks Int'l Ass'n, Local 1625 v. Schermerhorn, 375 U.S. 96, 103 (1963))).

68. See Pac. Gas \& Elec. Co. v. State Energy Res. Conservation \& Dev. Comm'n, 461 U.S. 190,203 (1983) ("It is well established that within constitutional limits Congress may pre-empt state authority by so stating in express terms.").

69. Geier v. Am. Honda Motor Co., 529 U.S. 861, 873 (2000) (quoting Hines v. Davidowitz, 312 U.S. 52, 67 (1941)); see also Jones v. Rath Packing Co., 430 U.S. 519, 526 (1977).

70. Implied conflict preemption is generally understood to have two components. As the Court has explained, "We have found implied conflict pre-emption where it is impossible for a private party to comply with both state and federal requirements, or where state law stands as an obstacle to the accomplishment and execution of the full purposes and objectives of Congress." Freightliner Corp. v. Myrick, 514 U.S. 280, 287 (1995) (internal quotation marks and citations omitted). We focus on the second of these components, though we recognize that "the categories of preemption are not 'rigidly distinct."' Crosby v. Nat'l Foreign Trade Council, 530 U.S. 363, 372 n.6 (2000) (quoting English v. Gen. Elec. Co., 496 U.S. 72,79 n.5 (1990)).

71. Rice v. Santa Fe Elevator Corp., 331 U.S. 218, 230 (1947).

72. Geier, 529 U.S. at 907 (Stevens, J., dissenting). 
should not be read to intrude upon state prerogatives (by, for example, abrogating state sovereign immunity or legislating in an area of traditional state concern) absent a clear statement from Congress that it intends to do so. ${ }^{73}$ In theory, such rules help ensure that "the structural safeguards inherent in the normal operation of the legislative process operate to defend state interests from undue infringement. ${ }^{, 74}$ Federalism is thus advanced through the "political safeguards" inherent in the structure of the federal government, ${ }^{75}$ by ensuring that an elected Congress composed of representatives of every State, not an unelected judiciary, is ultimately responsible for determining the extent to which federal law preempts state law. ${ }^{76}$

To be sure, one can recognize the political safeguards of federalism and still question whether the presumption against preemption and other clear statement rules reflect a sound understanding of federal power. Indeed, there is something to be said for the idea that as long as Congress acts within the bounds of its enumerated powers, its authority is plenary and the constitutional design has no particular preference for how to read federal statutes. ${ }^{77}$ Congress does not "alter[] the federal-state framework" enacting laws it is authorized to enact under the Constitution; it acts

73. See, e.g., Solid Waste Agency v. United States Army Corps of Eng'rs, 531 U.S. 159, 173 (2001) (noting the requirement that Congress speak clearly if it intends to invoke the outer limits of its authority, and stressing that " $[t]$ his concern is heightened where the [exercise of federal power in question] alters the federal-state framework by permitting federal encroachment upon a traditional state power"); Gregory v. Ashcroft, 501 U.S. 4S2, 460-64 (1991); United States v. Bass, 404 U.S. 336, 349 (1971) ("[U]nless Congress conveys its purpose clearly, it will not be deemed to have significantly changed the federal-state balance.... In traditionally sensitive areas, such as legislation affecting the federal balance, the requirement of clear statement assures that the legislature has in fact faced, and intended to bring into issue, the critical matters involved in the judicial decision.").

74. Geier, 529 U.S. at 907 (Stevens, J., dissenting).

75. See Garcia v. San Antonio Metro. Transit Auth., 469 U.S. 528, 550-51 (1985) ("[T]he principal means chosen by the Framers to ensure the role of the States in the federal system lies in the structure of the Federal Government itself."); Ernest A. Young, State Sovereign Immunity and the Future of Federalism, 1999 SUP. CT. REV. 1, 23 (noting that the presumption against preemption "make[s] sure that the 'political safeguards of federalism' are fully operational"). The phrase "political safeguards of federalism" is most famously associated with Herbert Wechsler, The Political Safeguards of Federalism: The Role of the States in the Composition and Selection of the National Government, 54 COLUM. L. REV. 543, 543 (1954).

76. See Bradford R. Clark, Separation of Powers as a Safeguard of Federalism, 79 TEX. L. REV. 1321, 1429 (2001) ("By requiring the statute to be clear in this respect, the presumption ensures that Congress and the President rather than politically unaccountable judges-make the crucial decision to preempt state law through constitutionally prescribed lawmaking procedures designed to safeguard federalism."); Paul J. Mishkin, Some Further Last Words on Erie-the Thread, 87 HARV. L. RFV. 1682, 1683, 1685 (1974) ("That Congress may have constitutional power to make federal law displacing state substantive policy does not imply an equal range of power for federal judges.... [T]he states, and their interests as such, are represented in the Congress but not in the federal courts.").

77. See Viet D. Dinh, Reassessing the Law of Preemption, 88 GEO. L.J. 2085, 2087-97 (2000).

78. Solid Waste Agency, 531 U.S. at 173. 
pursuant to that framework. Indeed, Viet Dinh has suggested that for the judiciary to "systematically favor" a finding of no preemption would "risk an illegitimate expansion of the judicial function." "If anything, Dinh suggests, "the logic and the principles animating the Supremacy Clause would seem to suggest . . . a bias in favor of preemption, not against." ${ }^{\prime 80}$ But whatever the merits of these objections as a matter of first principles, the presumption against preemption is clearly a mainstay of conflict preemption doctrine in a range of cases.

The presumption does not apply in all cases, however. Indeed, a second, and countervailing, rule is that the presumption is inapplicable "when the State regulates in an area where there has been a history of significant federal presence." ${ }^{, 81}$ Where, for example, a State attempts to regulate commercial maritime traffic operating in United States waters, the strong historical federal interest in national and international maritime commerce militates against any presumption in favor of state regulation. ${ }^{82}$ Similarly, in cases raising claims that a private actor has defrauded the federal agency that regulates it, there is no presumption in favor of applying state law to discipline the fraud. ${ }^{83}$ Courts are not obliged to attempt to accommodate concurrent state and federal regulation in areas like these, and the conflict between state and federal law "need not be as sharp" in order to support a finding of preemption. ${ }^{84}$

In general, therefore, the ease with which federal law preempts state law turns in large measure on how the area to be regulated is characterized as a threshold matter. ${ }^{85}$ If the case is understood to implicate core areas of traditional state power, then courts are properly reluctant to find preemption. But if it is viewed as a matter of special national concern

79. Dinh, supra note 77, at 2092.

80. Id. at 2094.

81. United States v. Locke, 529 U.S. 89, 108 (2000); see also United States v. Oakland Cannabis Buyers' Coop., 532 U.S. 483 (2001) (refusing to indulge any presumption against the preemptive force of federal drug laws vis-à-vis a California initiative permitting the use of marijuana for medical purposes).

82. See Locke, 529 U.S. at 108.

83. See Buckman Co. v. Plaintiffs' Legal Comm., 531 U.S. 341, 347 (2001) ("[T]he relationship between a federal agency and the entity it regulates is inherently federal in character because the relationship originates from, is governed by, and terminates according to federal law.").

84. Boyle v. United Techs. Corp., 487 U.S. 500, 507 (1988).

85. We emphasize again that the preemption inquiry assumes congressional authority to act in the area at issue in the first place. That is, whether there ought to be a presumption for or against preemption in a particular case does not bear on whether the federal law, regulation, or action at issue is a permissible exercise of a constitutionally enumerated federal power. These preemption principles are rather tools for disceming congressional intent, once the threshold question of congressional authority has been answered. 
traditionally subject to federal regulation, then the weight of interests is reversed and preemption is found more readily. ${ }^{86}$

Here we see the parallel to Supremacy Clause immunity. If the application of state criminal law against a federal officer is understood as an exercise of the State's traditional police power, then by analogy to preemption doctrine the presumption against preemption should apply. If, however, it is understood as implicating a special federal interest in protecting federal institutions and implementing federal policy, then standard preemption doctrine would suggest that the presumption ought not apply. As we explain more fully below, we think the second characterization is more persuasive, in part because state attempts to regulate the federal government directly constitute a special category of preemption in which the federal interest is particularly heightened.

\section{Direct State Regulation of the Federal Government}

In most preemption cases, the federal and state governments do not confront each other directly. Rather, as Laurence Tribe puts it, "the federalstate interaction [is] indirect: the question [is] how to allocate constitutional power as between the two levels of government when each seeks to deal with the same area of private conduct. ${ }^{, 87}$ But there is another class of cases bearing more directly on the issue of Supremacy Clause immunity: cases involving state attempts to regulate the federal government or its agents directly ${ }^{88}$ Although the federal-state interaction is much more immediate in such cases, we agree with Tribe that it, too, is best understood as an issue of federal preemption. ${ }^{89}$

86. We are mindful of the dangers of relying on reified, "categorical" notions of the "truly national" and "truly local." See Judith Resnik, Categorical Federalism: Jurisdiction, Gender, and the Globe, 111 YALE L.J. 619, 619, 622 (2001) (arguing against "categorical federalism" and in favor of "multi-faceted federalism"); see also Garcia v. San Antonio Metro. Transit Auth., 469 U.S. 528, 537 (1985) (disfavoring a method of constitutional analysis that would require judicial identification of "indisputabl[e] attributes of state sovereignty"). As Professor Resnik recognizes, however, a virtue of preemption doctrine is that it does not entail the kinds of "permanent categorization" at work in areas like the Supreme Court's Commerce Clause jurisprudence, where to define a particular subject as "truly local" is potentially to put it completely and irretrievably beyond the reach of the federal government. See Resnik, supra, at 629. Rather, the preemption doctrine provides a method for addressing the context-specific federal-state conflicts that arise in areas of overlapping federal and state regulation. See id. at 673-74. Preemption doctrine narrows the analysis to determining "whether, in a particular circumstance, legal regimes can cohabit and whether one set of rules needs to be set aside." $I d$. at 673 . In part, that determination entails weighing the competing sovereign interests at stake in the case at hand.

87. LAURENCE H. TRIBE, AMERICAN CONSTITUTIONAL LAW 511 (2d ed. 1988).

88. See Johnson v. Maryland, 254 U.S. 51, 55 (1920) (distinguishing between cases "deal[ing] with the conduct of private persons in matters in which the States as well as the general govemment have an interest," and cases involving attempts by a State to "interrupt the acts of the general government itself').

89. See TRIBE, supra note 87, at 511. 
As in preemption cases more generally, Congress could, of course, expressly preempt state regulation of particular federal agents or instrumentalities. ${ }^{90}$ Alternatively, Congress could expressly incorporate state law as a constraint on federal actors. It could provide, for example, that federal law enforcement officers are fully subject to the mandates of state criminal law when they act in the field. In the absence of any express congressional treatment of the issue, the operative question is the same as in implied conflict preemption cases more generally: Does the state regulation threaten to interfere with federal interests? Congress is presumed not to consent to state regulation that interferes with federal law and policy; the point at which such interference arises marks the outer boundary of Congress's implied consent to state regulation. ${ }^{91}$

This concern with interference was expressed as early as McCulloch $v$. Maryland, ${ }^{92}$ where the Supreme Court held that the Supremacy Clause prevented Maryland from taxing bank notes issued by the newly created Bank of the United States. The federal statute creating the Bank gave it a range of powers, including the authority "generally to do and execute all and singular the acts, matters, and things, which ... it shali or may appertain to do." ${ }^{93}$ The statute also expressly authorized the creation of branch offices, ${ }^{94}$ and the Bank established one such office in Baltimore. Maryland subsequently passed a law assessing a tax on the issuance of bank notes by the Baltimore branch. ${ }^{95}$ The tax did not literally conflict with the federal statute creating the Bank, but its imposition threatened to frustrate the operation of a national institution. Such interference was intolerable:

[N]o principle [of state power] . . can be admissible, which would defeat the legitimate operations of a supreme government. It is of the very essence of supremacy, to remove all obstacles to its action within its own sphere, and so to modify every power vested in subordinate governments, as to exempt its own operations from their own influence. ${ }^{96}$

Accordingly, the Court struck down the tax. ${ }^{97}$

90. For a discussion of possible limits on congressional action of this sort, see infra Part $V$.

91. Cf. First Nat'l Bank v. Anderson, 269 U.S. 341, 347 (1926) ("[A]gencies of the United States created under its laws to promote its ... policies ... cannot be taxed under state authority except as Congress consents and then only in conformity with the restrictions attached to its consent.").

92. 17 U.S. (4 Wheat.) $316(1819)$.

93. An Act To Incorporate the Subscribers to the Bank of the United States, ch. 44, § 7, 3 Stat. 266,269 (1816).

94. \& 11,3 Stat. at 273 .

95. See McCulloch, 17 U.S. (4 Wheat.) at 320-22 (reproducing the text of the Maryland statute).

96. Id. at 427 .

97. See id. at 436. 
Part of the point in displacing state laws like the one at issue in $\mathrm{McC}$ ulloch is to ensure that a single State is not allowed to compromise the interests of people not represented in the organs of that State's government. ${ }^{98}$ As the Court explained, "In the legislature of the Union alone, all are represented. The legislature of the Union alone, therefore, can be trusted by the people with the power of controlling measures which concern all, in the confidence that it will not be abused." "99 Accordingly, if an exercise of state regulatory power threatens to interfere with a federal institution, or to compromise the pursuit of federal policy, the state regulation is presumed preempted unless Congress specifies otherwise. ${ }^{100}$ In preemption parlance, the state law is preempted to the extent it interferes with federal law and policy, subject (as always) to congressional amendment of federal law to accommodate the state regulation.

The focus here is on actual interference. ${ }^{101}$ If applying state law in a given context would not interfere with federal institutions or frustrate federal policy, then there is no preemption. ${ }^{102}$ This is in part a rule of necessity: If federal agents were immune from all state laws, Congress would be required to "undertake the overwhelming burden of having to provide a comprehensive body of rules to govern all of the rights and obligations of all those who act on its behalf, including 'the mode of turning at the corners of streets. ${ }^{\prime 103}$ But where state law does threaten interference with federal prerogatives, McCulloch's concerns about a single State

98. See Laurence H. Tribe, Intergovernmental Immunities in Litigation, Taxation, and Regulation: Separation of Powers Issues in Controversies About Federalism, 89 HARV. L. REV. 682, 701-02 (1976) (discussing McCulloch's noninterference principle).

99. McCulloch, 17 U.S. (4 Wheat.) at 431 ; see also id. at 429 (explaining that "the people of a single state cannot confer a sovereignty which will extend" over "the people of the United States").

100. See Osborn v. Bank of the United States, 22 U.S. (9 Wheat.) 738, 865 (1824) (rejecting the argument that the presumption should run the other way).

101. See Tribe, supra note 98, at 701-02. McCulloch also noted that the Maryland tax applied only to the Bank of the United States, and in that sense specially discriminated against the federal government. See 17 U.S. (4 Wheat.) at 436. Later decisions have stressed that aspect of McCulloch's reasoning. See, e.g., Graves v. New York, 306 U.S. 466, 477 (1939); James v. Dravo Contracting Co., 302 U.S. 134, 149 (1937). These and other cases concerning intergovernmental tax immunity constitute a rather tortured jurisprudence the contours of which are formed by a number of factors not immediately relevant here. See generally TRIBE, supra note 87, at 514-21 (discussing the scope of federal tax immunity and the role of Congress in intergovernmental immunity cases). We do not deny that $\mathrm{McC}$ ulloch can be read to stand for a nondiscrimination principle separate from the noninterference principle we emphasize here, and our argument does not depend on assigning primacy to the latter over the former. Rather, we merely rely on that part of $\mathrm{McCulloch}$ that we think casts the most analytical light on Supremacy Clause immunity, without regard to the precise weight of the noninterference principle in contemporary doctrine.

102. See Nat'l Bank v. Kentucky, 76 U.S. (9 Wall.) 353, 362 (1869) ("[A]gencies of the Federal government are only exempted from State legislation, so far as that legislation may interfere with, or impair their efficiency in performing the functions by which they are designed to serve that government.").

103. TRIBE, supra note 87, at 513 (quoting Johnson v. Maryland, 254 U.S. 51, 56 (1920) (Holmes, J.)). 
dictating policy to the entire nation counsel in favor of preemption-that is, federal immunity from state regulation.

Two additional points bear emphasizing here. First, the presumption against preemption has little, if any, role to play in cases involving state attempts to regulate the federal government or its agents directly. Although the Supreme Court's cases tend not to address the point in terms, it seems clear that when a State attempts to regulate the federal government, it acts in an area of quintessentially heightened federal interest. State laws of general applicability may well fall within zones of traditional state authority - the police power, for example-but when applied to the federal government and its agents, such laws extend beyond their traditional compass. There is therefore little reason to strain to preserve a role for the States in such cases. More specifically, courts will not-and, we think, should not-infer from legislative silence a congressional intent to subject the federal government or its agents to direct state regulation interfering with the effectuation of federal law or policy. Rather, if direct state regulation of federal actors at all interferes with federal law or policy, courts will hold it preempted.

Second, and critically, the preemption analysis in this area need not train on the specific provisions of a particular federal enactment. In typical preemption cases, the federal-state interaction is between two laws or regulations of general applicability. The preempting instrument is thus usually a federal statute, or in some cases a federal regulation. ${ }^{104}$ In cases involving state attempts to regulate the federal government or its agents directly, however, there is often no single federal law or regulation to which one can point as the specific instrument of preemption. One may be able to identify an organic federal statute authorizing the creation of the federal institution in question, but that statute itself will likely lack the specificity ordinarily required to trigger preemption. Instead, the preempting impetus comes from the principle, implicit in the constitutional order itself, of state noninterference with federal institutions and prerogatives. In $\mathrm{McCulloch}$, for example, the Court did not rely upon any particular federal statute with which the state tax conflicted. ${ }^{105}$ Instead, having concluded that Congress

104. See Fidelity Fed. Sav. \& Loan Ass'n v. de la Cuesta, 458 U.S. 141, 153-54 (1982) (observing that federal regulations may have preemptive force).

105. See 17 U.S. ( 4 Wheat) at 426 ("There is no express provision for the case ..."). As Caleb Nelson observes, Chief Justice Marshall's opinion for the Court in Osborn v. United States, 22 U.S. ( 9 Wheat.) 738 (1824), describes McCulloch in more statutory terms. See Caleb Nelson, Preemption, 86 VA. L. REV. 225, 270-71 (2000). Osborn depicts the federal statute authorizing the Bank as reflecting Congress's judgment that the Bank should have all powers "necessary, to enable the Bank to perform the services ... for which it was created." 22 U.S. (9 Wheat.) at 864. Because state regulation could compromise the Bank's effectiveness, Osborn reasons, the federal statute "exempt[ed] the trade of the Bank ... from the control of the States." Id. at 866. In this sense, one might rely on Osborn to read McCulloch as a simple case of ordinary statutory preemption. See Nelson, supra, at 271 ("To judge from Osborn, then, Marshall read the federal 
had the constitutional power to create the Bank of the United States, ${ }^{106}$ the Court broadly considered the federal interests in the Bank and struck down the state tax because it interfered with those interests. ${ }^{107}$ " [T] he power to tax involves the power to destroy," the Court famously observed, ${ }^{108}$ and permitting a State to tax the Bank of the United States without express federal consent would thus give States the power to disable the federal government and make it "dependent on the states." 109 That result would make a mockery of the Court's conclusion that Congress was competent to create the Bank in the first place: " $[\mathrm{A}]$ power to create implies a power to preserve." 110

This approach makes sense. In typical preemption cases, the operative federal interests and policies are embodied in federal statutes. Indeed, absent congressional enactments governing a particular area of private conduct, there is often little basis for identifying any determinate federal interest in the area. ${ }^{11}$ Cases involving state attempts to regulate the federal government or its agents directly, in contrast, implicate an inherent federal interest in the efficient operation of the federal government and the effective execution of federal policy. ${ }^{12}$ Those interests may be inferred from the organic statute authorizing the creation of the federal institution, ${ }^{113}$

statute creating the Bank to contradict state laws taxing its operations."). But that would take Osborn too far. Osborn acknowledges that the statute creating the Bank did not "cxpressly asser[t]" a federal exemption from state regulation. 22 U.S. (9 Wheat.) at 865 . It explains, however, that "[i]t is no unusual thing for an act of Congress to imply, without expressing, this very exemption from State control." Id. At this point, however, Osborn is no longer relying on anything in the federal statute itself. Rather, it is describing the same implicit federal immunity from state interference that we infer from the constitutional design.

106. See McCulloch, 17 U.S. (4 Wheat.) at 401-25.

107. See id. at 436 (holding that the Constitution does not permit States "by taxation or otherwise, to retard, impede, burden, or in any other manner control, the operations of the constitutional laws enacted by congress to carry into execution the powers vested in the general government").

108. Id. at 431.

109. Id. at 432.

110. Id. at 426.

111. There are, of course, some areas that the Constitution specially reserves to the federal government, restricting the power of the States to act even in the absence of any federal law or action in the field. The "dormant" Interstate and Foreign Commerce Clauses are leading examples. See, e.g., Japan Line, Ltd. v. County of Los Angeles, 441 U.S. 434, 435-36 (1979) (Foreign Commerce Clause); City of Philadelphia v. New Jersey, 437 U.S. 617, 617 (1978) (Interstate Commerce Clause). Although the state laws at issue in cases implicating these provisions generally involve the regulation of third parties, structurally the analysis is akin to the analysis we have described with respect to state attempts to regulate the federal government directly.

112. See Tennessee v. Davis, 100 U.S. 257, 263 (1880) ("No State gavernment can exclude [the federal government] from the exercise of any authority conferred upon it by the Constitution [or] obstruct its authorized officers against its will ...." (emphasis added)); Martin v. Hunter's Lessee, 14 U.S. (1 Wheat.) 304, 363 (1816) (Johnson, J., concurring) ("[T] he general government must cease to exist whenever it loses the power of protecting itself in the exercise of its constitutional powers.").

113. See supra note 105 and accompanying text. 
but the statute need not expressly articulate them because they are implicit in the federal government itself. And as McCulloch makes clear, the constitutional provision for federal supremacy protects interests of that order from state interference. ${ }^{114}$ The primary question, then, is whether the state law or regulation at issue threatens to interfere with the federal government's inherent interest in the integrity of its institutions and the pursuit of its policies. ${ }^{115}$ As we shall see, Supremacy Clause immunity is best conceptualized as asking the same kind of question.

\section{STATE CONSTRAINTS ON FEDERAL LAW ENFORCEMENT}

Having outlined the background immunity and preemption principles pertinent here, we turn more directly to the power of a State to constrain the conduct of federal law enforcement officers. As suggested by the foregoing discussion of Idaho v. Horiuchi, ${ }^{116}$ there are two general questions in this area: Who may adjudicate state actions against federal officers, and what law applies?

The venue and substance questions implicate distinct, though complementary, federal interests. As to venue, the principal federal interest is in protecting federal officers from state hostility toward the federal government. In Horiuchi, for example, local sympathy may have run strongly with the separatists at Ruby Ridge, and a state judge elected by the local citizenry may have found it difficult to ensure a fair trial. Accordingly, as we explain below, ${ }^{117}$ since the early nineteenth century a succession of federal statutes has allowed Horiuchi and federal officers like him to remove state prosecutions to federal court as a way to protect against the potential biases of in-state proceedings.

If protecting against state judicial or prosecutorial bias were the only federal interest in play, then there would be no need for a substantive immunity doctrine. Removal to federal court would suffice. But as McCulloch reveals, even good-faith state attempts to regulate the federal government or its agents can work substantive interference with federal

114. See Nelson, supra note 105, at 269 ("[O]ne could read $M c C$ ulloch to hold that structural principles in the Constitution establish a doctrine of intergovernmental immunities: In the absence of congressional consent, states cannot exercise sovereign powers over federal instrumentalities."); Tribe, supra note 98, at 700 ("[A] residual [federal] immunity [from direct state regulation interfering with federal functions] may... be inferred from the plan of the Constitution.").

115. See Nat'l Bank v. Kentucky, 76 U.S. (9 Wall.) 353, 362 (1869) ("[A]gencies of the Federal govemment are only exempted from State legislation, so far as that legislation may interfere with, or impair their efficiency in performing the functions by which they are designed to serve that government.").

116. See supra Part I.

117. See infra Section III.A. 
laws or policies. ${ }^{118}$ In the context of state criminal prosecutions, that interference can be twofold. First, subjecting federal officers to state criminal law can require officers like Horiuchi to acquaint themselves with up to fifty potentially different normative regimes, depending on where in the country they are deployed. Second, even if the laws of all States are uniform on a particular point, application of those laws against federal officers may compromise the federal laws and policies they are charged with effectuating, just as Maryland's tax threatened to impede the operation of the National Bank.

To protect against both of these intrusions, the Supreme Court has for over a century recognized some form of Supremacy Clause immunity. The Court has not, however, clearly defined the scope of that immunity. In the absence of express direction from Congress to the contrary, we argue in this Part that something akin to officers' qualified immunity from $\S 1983$ or Bivens liability is appropriate. We apply that standard, moreover, not just to cases involving state criminal law, but also to state civil law and to state rights of action to enforce federal constitutional norms. ${ }^{119}$

\section{A. Venue}

As described above, Idaho initiated its prosecution of Agent Horiuchi in state court and Horiuchi subsequently removed it to federal court. This raises a question: Setting aside issues of what substantive law applies, are state courts ever competent to adjudicate the lawfulness of federal officers' conduct in discharging their federal duties? In general, the answer lies with Congress.

Consider Tarble's Case, ${ }^{120}$ which involved the question whether a state court had jurisdiction in habeas corpus to examine the legality, under federal law, of an individual's enlistment and confinement in the United States Army. Observing that federal law did not grant the States jurisdiction to review such federal questions, the Court concluded that no other source could confer that jurisdiction and thus that the States did not have it. ${ }^{121}$ The

118. See supra notes $92-103$ and accompanying text.

119. We stress that Supremacy Clause immunity - whatever its scope-does not apply to all potential forms of state regulation of the federal government. Like qualified immunity, it insulates federal officers from personal civil or criminal liability arising out of ex post challenges to their conduct. It does not apply, however, in cases where a State or individual seeks prospective relief from a particular federal law, policy, or practice. Thus, for example, if Idaho (or, for that matter, one of the Weavers) had known in advance about the FBI's plan to use certain rules of engagement at the Ruby Ridge standoff, and had brought an action seeking to enjoin use of those rules on the ground that they were unconstitutional or otherwise unlawful, Supremacy Clause immunity would have had no role to play in the litigation.

120. 80 U.S. (13 Wall.) 397 (1872).

121. The Court stated that jurisdiction 
Court stressed that it was for the federal government to decide how and where its laws would be implemented, and that permitting state courts to adjudicate federal questions in the absence of an appropriate jurisdictional delegation would risk subjecting the federal government to intolerable interference. ${ }^{122}$ Accordingly, the proper recourse in Tarble's Case was for the detainee to file a habeas petition in federal court under the federal habeas statute. ${ }^{123}$

As Martin Redish and Curtis Woods have observed, "Tarble's Case represents the culmination of a struggle between the forces supporting widespread statc sovereignty and those in favor of a strong and supreme national government, a struggle which climaxed in the Civil War." 124 The Civil War confirmed the supremacy of the federal government over the States; Tarble's Case protected that supremacy by shielding the federal government from state court interference, and also from the antifederal bias that subsisted in many States after the war. ${ }^{125}$

Although Tarble's Case is thus relatively easy to grasp as a historical matter, the precise jurisprudential basis of the decision has been the subject of considerable debate. ${ }^{126}$ Some have suggested it rests on the proposition

certainly has not been conferred on [state courts] by the United States; and it is equally clear it was not in the power of the State to confer it, even if it had attempted to do so; for no State can authorize one of its judges or courts to exercise judicial power, by habeas corpus or otherwise, within the jurisdiction of another and independent government.

Id. at 405 .

122. Id. at 407-08 (noting that questions of "[h]ow ... [federal] laws shall be enacted; how they shall be carried into execution; and in what tribunals, or by what officers; and how much discretion, or whether any at all shall be vested in their officers, are matters subject to [the federal government's] own control"); $i d$. at 409 ("It is manifest that the powers of the National government could not be exercised with energy and efficiency at all times, if its acts could be interfered with and controlled for any period by officers or tribunals of another sovereignty.").

123. Id. at 411 (observing the availability of federal habeas relief for those unlawfully confined under federal law).

124. Martin H. Redish \& Curtis E. Woods, Congressional Power To Control the Jurisdiction of Lower Federal Courts: A Critical Review and a New Synthesis, 124 U. PA. L. REV. 45, 97 (1975).

125. See id. at $97-100$.

126. See, e.g., Richard S. Arnold, The Power of State Courts To Enjoin Federal Officers, 73 YALE L.J. 1385, 1390-91 (1964) ("Justice Field's language [in Tarble's Case] indicates that the Constitution forbids state jurisdiction ex proprio vigore."); Michael G. Collins, Article III Cases, State Court Duties, and the Madisonian Compromise, 1995 WIS. L. REV. 39, 102-03 (noting that "it is possible to read Tarble ... not as about constitutionally exclusive jurisdiction, but as merely expressing an implicit congressional preference for federal statutory exclusivity in federal officer habeas cases when Congress has provided such jurisdiction in the federal courts," but also stressing that "the effort to rationalize the outcome in Tarble should not obscure the fact that the jurisdictional incapacity of state courts in this area still represented, for the old Court, a kind of constitutional common-law generated by structural and supremacy concerns"); Daniel J. Meltzer, Congress, Courts, and Constitutional Remedies, 86 GEO. L.J. 2537, 2567 (1998) (arguing that the case is "unsound insofar as it suggests that the Constitution precludes state court habeas corpus jurisdiction against federal officials," and recommending "hesitat[ion] [before] mak[ing] a constitutional argument dependent on the continuing force of a constitutional reading of that decision"); Redish \& Woods, supra note 124, at 101 ("Tarble's Case can ... be read to create a 
that the Constitution prohibits the States from subjecting federal officials to habeas corpus jurisdiction, and that even Congress may not overcome that prohibition by ceding jurisdiction to the States. ${ }^{127}$ But that thesis seems inconsistent with the Madisonian Compromise during the framing of the Constitution, which produced the Article III provision that authorizes, but does not require, Congress to establish lower federal courts. ${ }^{128}$ By allowing Congress to decide whether to establish such courts, Article III contemplates that to the extent Congress chooses not to establish them, it can grant state courts original jurisdiction to adjudicate questions arising under federal law. ${ }^{129}$ Were it otherwise, Congress's decision not to establish lower federal courts would mean that some federal questions might not be adjudicated in any court. That outcome would raise serious constitutional concerns, at least where the federal question involves the assertion of rights protected by the Constitution. ${ }^{130}$

presumption that state courts, under the supremacy clause, are powerless to control directly the actions of federal officers. This presumption, premised on the practical realities and fundamental philosophy of our federal system, can be overcome only by a carefully considered, conscious decision by Congress that, in a specific area, state court power over the actions of federal officers is permissible.").

127. See, e.g., Arnold, supra note 126, at 1390-91.

128. See U.S. CONST. art. III, $\S 1$ ("The judicial Power of the United States, shall be vested in one supreme Court, and in such inferior Courts as the Congress may from time to time ordain and establish."). See generally HART \& WECHSLER, supra note 46, at 7-9 (describing the Compromise).

129. See HART \& WECHSLER, supra note 46, at 463 (noting tension between "the proposition that the Constitution precludes state habeas corpus jurisdiction over federal officers," and "the Madisonian Compromise and the language of Article III making the establishment of 'inferior' federal courts a matter of congressional discretion").

130. If Tarble's Case rests on an indefeasible constitutional prohibition of state jurisdiction, then the decision runs headlong into the traditional understanding that Congress was under no obligation to create lower federal courts. If state courts were constitutionally disabled from hearing such cases, and if Congress might create no lower federal courts, there would be no habeas forum available to redress illegal detention at the hands of federal officers.

Collins, supra note 126, at 101-02. Collins slightly overstates the matter, as review might still be available in the Supreme Court pursuant to an original petition for a writ of habeas corpus. Section 14 of the Judiciary Act of 1789 granted all federal courts, including the Supreme Court, jurisdiction to entertain habeas petitions filed by prisoners "in custody, under or by colour of the authority of the United States, or committed for trial before some court of the same." Judiciary Act of 1789 , ch. $20, \S 14,1$ Stat. 73, 82. The modern version of that provision, which is separate from the Supreme Court's appellate jurisdiction to review the disposition of habeas petitions originally filed in the lower courts, is found at 28 U.S.C. $\$ 2241$ (a) (2000): "Writs of habeas corpus may be granted by the Supreme Court, any justice thereof, the district courts and any circuit judge within their respective jurisdictions." $C f$. Felker v. Turpin, 518 U.S. 651, 658-62 (1996) (construing statutory restrictions on habeas jurisdiction in the lower federal courts not to apply to the Court's jurisdiction to entertain original habeas petitions). Had Congress not created any lower federal courts, it presumably could have vested this "original" jurisdiction in the Supreme Court alone. See id. at 667 n.1 (Souter, J., concurring) (noting that an original habeas petition "is commonly understood to be 'original' in the sense of being filed in the first instance in this Court, but nonetheless for constitutional purposes an exercise of this Court's appellate (rather than original) jurisdiction"). Even so, the theoretical availability of original habeas review in the Supreme Court may well have fallen far short of a fully adequate remedy for unlawful federal detention. 
Given these difficulties, a better reading of Tarble's Case is that it reflects the Court's conclusion that Congress had invested only the federal courts with habeas jurisdiction to review the legality of federal detention. ${ }^{131}$ Congress could have conferred similar jurisdiction on the States, but it did not. ${ }^{132}$ And in the absence of such a conferral, the Court held that to permit a state court to exercise jurisdiction would conflict with the federal statutory scheme established by Congress. ${ }^{133}$ This reading is consistent with later pronouncements by the Court that Congress has virtually complete discretion to decide whether state courts shall have jurisdiction to adjudicate federal questions. ${ }^{134}$ In Tarble's Case, the Court simply concluded that the pertinent statutes reflected an implicit congressional determination that state jurisdiction was not appropriate.

The analysis is similar, but not identical, when the case arises under state law in the first instance. Of course, state courts do not require congressional authorization to adjudicate cases arising under their own laws. Sometimes, however, a case also implicates a federal question-where, for example, the defendant is a federal officer and asserts a federal defense to state liability, as Agent Horiuchi did. That federal question then becomes a basis for Congress to provide for federal jurisdiction. ${ }^{135}$ Of course, if Congress chose not to act then these sorts of cases would remain in state court; as discussed above, conflict preemption doctrine teaches that state jurisdiction over matters of traditional state concern is not displaced unless its exercise conflicts with federal law. ${ }^{136}$ But if Congress does wish to provide for federal jurisdiction, it may preempt state jurisdiction altogether or, alternatively, provide for federal jurisdiction concurrent with that of the States. ${ }^{137}$

131. See HART \& WECHSLER, supra note 46 , at 465 ; Collins, supra note 126 , at 102 ; Redish \& Woods, supra note 124 , at $97-101$.

132. See Amar, Questions and Answers, supra note 19, at 165 ("[O]f course, Congress could overrule [Tarble's] holding anytime it wanted by providing for concurrent or exclusive state court jurisdiction over habeas trials.").

133. Cf. Johnson v. Maryland, 254 U.S. 51, 56-57 (1920) (Holmes, J.) (suggesting in dicta that federal officers are not subject to state courts' jurisdiction in matters under explicit federal authority).

134. See City of Greenwood v. Peacock, 384 U.S. 808, 833 (1966). In Greenwood, the Court asserted:

We may assume that Congress has constitutional power to provide that all federal issues be tried in the federal courts, that all be tried in the courts of the States, or that jurisdiction of such issues be shared. And in the exercise of that power, we may assume that Congress is constitutionally fully free to establish the conditions under which civil or criminal proceedings involving federal issues may be removed from one court to Id. another.

135. See Tennessee v. Davis, 100 U.S. 257 (1880). We discuss Davis in greater detail below. See infra notes 147-148 and accompanying text.

136. See supra notes 71-80 and accompanying text.

137. See City of Greenwood, 384 U.S. at 833. 
Since 1815, Congress has permitted the removal to federal court of certain state suits and prosecutions against certain federal officers. ${ }^{138}$ The earliest grants of removal power were only temporary, and were enacted in response to specific fears that federal officers would receive unfair treatment in state court. The 1815 statute, for example, was a response to New England's resistance to the War of 1812 and to the risk that federal officers charged with enforcing the trade embargo with England would meet with hostility in New England. ${ }^{139}$ That statute expired after the end of the war, but in 1833 Congress provided for a similar right of removal in the so-called Force Bill, which was a response to South Carolina's threats of nullification. ${ }^{140}$ Congress later passed a new set of removal statutes during the Civil War, sometimes extending older acts. ${ }^{141}$ Those various provisions were amended a number of times after the war ${ }^{142}$ until Congress finally included a removal provision covering all federal officers in the Judicial Code of $1948 .{ }^{143}$

The current removal statute is codified at 28 U.S.C. $\S 1442$ (a). Among other things, that provision permits any federal officer (or person acting under that officer) to remove any state civil action or criminal proceeding initiated against him for any act under color of his office or on account of any federal authority granted to him to apprehend or punish criminals. ${ }^{144}$ This right of removal, the Supreme Court has concluded, applies only when the federal officer raises a colorable federal defense to the underlying suit or prosecution. ${ }^{145}$ Provided the officer raises such a defense, the case implicates the federal courts' Article III jurisdiction of cases "arising

138. See Act of Feb. 4, 1815, ch. 31, § 8, 3 Stat. 195, 198-99; see also Act of Mar. 3, 1815, ch. 94, $\$ 6,3$ Stat. 231, 233-34, extended for one year by Act of Apr. 27, 1816, ch. 110, $\$ 3$, 3 Stat. 315, 315, and extended for an additional four years by Act of Mar. 3, 1817, ch. 109, $\S \S 2$, 6, 3 Stat. 396, 397.

139. See Willingham v. Morgan, 395 U.S. 402, 405 (1969); HART \& WECHSLER, supra note 46, at 951; Andrew J. Field, Removing State Criminal Charges Against a Federal Officer to Federal Court, CRIM. JUST., Winter 2000, at 20, 21.

140. See Act of Mar. 2, 1833, ch. 57, §§ 2-3, 4 Stat. 632, 633-34; see also Willingham, 395 U.S. at 405 .

141. See Act of July 27, 1868, ch. 276, § 1, 15 Stat. 243, 243; Act of July 28, 1866, ch. 298, $\S 8,14$ Stat. 328, 329; Act of July 13, 1866, ch. 184, $\S \S 67-68,14$ Stat. 98, 171-72; Act of June 30,1864 , ch. 173, $\S 50,13$ Stat. 223, 241; Act of Mar. 7, 1864, ch. 20, $\$ 9,13$ Stat. 14, 17; Act of Mar. 3,1863 , ch. $81, \S 5,12$ Stat. $755,756-57$, amended by Act of May 11,1866 , ch. 80 , $\S \S 3-4$, 14 Stat. 46, 46, and Act of Feb. 5, 1867, ch. 27, 14 Stat. 385. See generally HART \& WECHSLER, supra note 46 , at 951 \& $\mathrm{nn} .3-4$ (cataloguing removal statutes passed during and immediately following the Civil War).

142. See, e.g., Act of Aug. 23, 1916, ch. 399, 39 Stat. 532; Act of Mar. 3, 1911, ch. 231, § 33, 36 Stat. 1087, 1097; see also Willingham, 395 U.S. at 405-06.

143. See Willingham, 395 U.S. at 406; H.R. REP. NO. 80-308, at A134 (1947).

144. 28 U.S.C. \& $1442(\mathrm{a})(1)(2000)$.

145. See Mesa v. California, 489 U.S. 121, 139 (1989). 
under" federal law and thus may properly be adjudicated in federal court if the defendant so elects. ${ }^{146}$

The constitutionality of this form of removal was first challenged during Reconstruction. In Tennessee v. Davis, the Court considered the argument that

it is an invasion of the sovereignty of a State to withdraw from its courts into the courts of the general government the trial of prosecutions for alleged offenses against the criminal laws of a State, even though the defence presents a case arising out of an act of Congress. ${ }^{147}$

The Court rejected that argument as "ignor[ing] entirely the dual character of our government":

[W]hen the national government was formed, some of the attributes of State sovereignty were partially, and others wholly, surrendered and vested in the United States.... Before the adoption of the Constitution, each State had complete and exclusive authority to administer by its courts all the law, civil and criminal, which existed within its borders. Its judicial power extended over every legal question that could arise. But when the Constitution was adopted, a portion of that judicial power became vested in the new government created, and so far as thus vested it was withdrawn from the sovereignty of the State. Now the execution and enforcement of the laws of the United States, and the judicial determination of questions arising under them, are confided to another sovereign, and to that extent the sovereignty of the State is restricted. The removal of cases arising under those laws, from State into Federal courts, is, therefore, no invasion of State domain. On the contrary, a denial of the right of the general government to remove them ... is a denial of the conceded sovereignty of that government over a subject expressly committed to it. ${ }^{148}$

This is not to say that the removal of state criminal prosecutions to federal court does not implicate state interests. It surely does. But so long as

146. Basing federal jurisdiction on matters asserted by the defendant is an exception to the well-pleaded complaint rule. See Jefferson County v. Acker, 527 U.S. 423, 430-31 (1999) ("To remove a case as one falling within federal-question jurisdiction, the federal question ordinarily must appear on the face of a properly pleaded complaint; an anticipated or actual federal defense generally does not qualify a case for removal. ... Suits against federal officers are exceptional in this regard. Under the federal officer removal statute, suits against federal officers may be removed despite the nonfederal cast of the complaint; the federal-question element is met if the defense depends on federal law."); Mesa, 489 U.S. at 136 (characterizing the removal statute as an exception to the well-pleaded complaint rule).

147. 100 U.S. $257,266(1880)$.

148. Id. at 266-67. 
the removed case is also subject to federal jurisdiction, the fact that state interests are implicated does not impose any additional constitutional barrier to removal. This is the Supremacy Clause at work.

As we have already suggested, ${ }^{149}$ removal in cases like Horiuchi serves substantial federal interests. Indeed, from the War of 1812 to the standoff at Ruby Ridge, the same federal-state clashes that produced state prosecutions of federal officers also generated risks of antifederal bias in the state courts. Providing a federal forum protects federal officers-and by extension the federal government-from state courts' potential hostility to federal policies and institutions. ${ }^{150}$

The federal interest in these cases extends beyond matters of venue, however. Equally pressing is the substantive immunity question itself. Indeed, as the Supreme Court has explained, "one of the most important reasons for removal is to have the validity of the defense of official immunity tried in a federal court." ${ }^{\text {"51 }}$ Having established the availability of removal, we next turn to the States' substantive power to constrain federal officers, and to those officers' immunity from such constraints.

\section{B. State Criminal Law and Supremacy Clause Immunity}

As the Tenth Amendment reflects, state sovereignty over areas like criminal law is plenary except to the extent it touches upon a constitutionally enumerated power of the federal government. A State's exercise of its police power typically does not implicate federal interests, and thus is not circumscribed by them. But where, as in Horiuchi, a State attempts to impose criminal sanctions on a federal officer for actions taken in discharge of his federal duties, the risk of state interference with federal interests is particularly acute.

As the Court explained in Davis:

[The general government] can act only through its officers and agents, and they must act within the States. If, when thus acting,

149. See supra notes $116-117$ and accompanying text.

150. See Willingham v. Morgan, 395 U.S. 402,407 (1969) (noting that the officer removal statute reflects Congress's judgment that "federal officers, and indeed the Federal Government itself, require the protection of a federal forum"). There is a close parallel here to the purposes underlying federal diversity jurisdiction. See Guaranty Trust Co. v. York, 326 U.S. 99, 111 (1945) ("Diversity jurisdiction is founded on assurance to non-resident litigants of courts free from susceptibility to potential local bias."); Pease v. Peck, 59 U.S. (18 How.) 595, 599 (1855) ("The theory upon which jurisdiction is conferred on the courts of the United States, in controversies between citizens of different States, has its foundation in the supposition that, possibly, the state tribunal might not be impartial between their own citizens and foreigners."). The parallel is made even closer by the fact that when Congress first granted diversity jurisdiction in the Judiciary Act of 1789 , ch. $20, \S 11,1$ Stat. 73,78 , it also granted a corresponding removal jurisdiction enabling out-of-state defendants to remove suits against them filed by in-state plaintiffs, $\S 12,1$ Stat. at 79 .

151. Willingham, 395 U.S. at 407. 
and within the scope of their authority, those officers can be arrested and brought to trial in a State court, for an alleged offence against the law of the State, yet warranted by the Federal authority they possess, and if the general government is powerless to interfere at once for their protection... the operations of the general government may at any time be arrested at the will of one of its members. ${ }^{152}$

In short, subjecting federal officers to state criminal sanctions for carrying out their federally appointed duties could make it extremely difficult, if not impossible, for the federal government to function. Even the most dedicated federal servant would be reluctant to do his job conscientiously if he knew it could mean prison time in the state penitentiary.

On the other hand, the mere fact of federal employment surely does not confer blanket immunity from state law. Why, for example, should a postal worker be permitted to escape state liability for harm caused by his reckless driving, simply because he was delivering mail at the time? ${ }^{153}$ The offending conduct has nothing to do with the employee's job-related responsibilities, and to penalize the conduct would not significantly compromise any federal interest. ${ }^{154}$ Indeed, to the extent there is any federal interest implicated at all, it is in confirming to federal employees that they may not drive recklessly while on the job. In such circumstances, States ought to, and do, retain the prerogative to enforce their laws as they see fit. $^{155}$

The difficulty, of course, lies in knowing where to draw the line. Where does a State's police function leave off and the effectuation of federal law

152. 100 U.S. at 263.

153. See Mesa v. California, 489 U.S. 121 (1989) (denying removal under the federal officer removal statute, 28 U.S.C. $\$ 1442$ (a) (2000), where the federal defendants alleged no colorable federal defense to the state charges of reckless driving and related offenses). Although Mesa is nominally about removal, a defendant's inability even to satisfy the standard for removing the prosecution to federal court confirms his inability to establish any entitlement to immunity from the prosecution itself. Thus, cases construing the contours of the removal statute also bear on the underlying question of immunity

154. Contrast this with the question whether a State may require a postal worker to procure a license from the State. In Johnson v. Maryland, the Supreme Court held postal workers immune from such requirements:

It seems to us that the immunity of the instruments of the United States from state control in the performance of their duties extends to a requirement that they desist from performance until they satisfy a state officer upon examination that they are competent for a necessary part of them and pay a fee for permission to go on. Such a requirement does not merely touch the Government servants remotely by a general rule of conduct; it lays hold of them in their specific attempt to obey orders and requires qualifications in addition to those that the Government has pronounced sufficient.

254 U.S. 51,57 (1920).

155. See Maryland v. Soper, 270 U.S. 9, 33 (1926) (holding that a federal officer seeking to remove a state prosecution to federal court "must by direct averment exclude the possibility that [the criminal charge] was based on acts or conduct of his not justified by his federal duty"). 
and policy begin? And in cases like Horiuchi, where the effectuation of federal law is left to the split-second judgments of an FBI agent deployed at a remote location to apprehend a heavily armed fugitive, what standard should courts apply in determining ex post whether the officer crossed that line?

\section{Doctrinal Foundations of Supremacy Clause Immunity}

There are remarkably few litigated cases addressing these questions. Perhaps predictably, the limited precedents that do exist tend to be clustered around historical moments of significant friction between the federal government and the States. In periods such as Reconstruction, ${ }^{156}$ Prohibition, ${ }^{157}$ and the Civil Rights Movement, ${ }^{158}$ federal officers enforcing certain aspects of federal law were particularly unpopular in some States. Attempts by States to subject federal officers to criminal sanctions tend to surface only at those historical moments when local disaffection with federal policies and their intervention into local life collide with particular force. 159

The leading Supreme Court precedent is In re Neagle, a fascinating 1890 case in which California sought to prosecute a United States deputy marshal who had been assigned to protect Supreme Court Justice Stephen Field during his annual circuit assignment in California. ${ }^{160}$ When an unhappy litigant stormed the Justice's dining car, the deputy (mistakenly

156. See, e.g., In re Hurst, 12 F. Cas. 1024, 1024 (M.D. Tenn. 1879) (No. 6926) (reviewing a state prosecution of a federal soldier for having killed a Confederate "bushwhacker" in a Civil War battle).

157. See, e.g., Soper, 270 U.S. at 9 (reviewing a state prosecution of federal prohibition officers for having allegedly killed a man during a raid on an illegal still in Hartford County, Maryland).

158. See, e.g., In re McShane's Petition, 235 F. Supp. 262 (N.D. Miss. 1964) (reviewing a state prosecution of a federal marshal for breach of the peace and unlawful use of force for having fired tear gas into a crowd while enforcing the right of James Meredith, an African American, to attend the University of Mississippi).

159. As Judge Hawkins put the matter in his Horiuchi dissent:

Whether protecting judges from the threats of dissatisfied litigants, revenue agents from local moonshiners, unpopular prisoners from intimidating mobs, wartime shipbuilders from striking workers, or a child from a volatile crowd protesting court-ordered school desegregation, federal agents enforcing the laws of the nation can, on thankfully rare occasions, come into conflict with those who enforce the criminal laws of the states.

Idaho v. Horiuchi, 253 F.3d. 359, 381 (9th Cir.) (en banc) (Hawkins, J., dissenting), vacated as moot, 266 F.3d 979 (9th Cir. 2001). The issue also occasionally arises in less high-profile cases. See, e.g., Gail Gibson, FBI Shooting Revives Legal Issue, BALT. SUN, June 19, 2002, at B1 (describing Maryland prosecutors' plan to seek an indictment against an FBI agent who mistakenly shot an unarmed man); William Glaberson, Defense Seeks To Move Drug Agent's Case, N.Y. TIMES, Nov. 23, 2002, at B3 (describing a manslaughter prosecution against a DEA agent for shooting an unarmed drug suspect in the back, and defense counsel's plan to remove the prosecution from New York state court to federal court and then to assert immunity). We express no view on the validity of any assertion of Supremacy Clause immunity in these cases.

I60. 135 U.S. 1 (1890). 
believing the man was armed) shot and killed him. ${ }^{161}$ The Supreme Court held the deputy immune from state prosecution, explaining:

[I]f the prisoner is held in the state court to answer for an act which he was authorized to do by the law of the United States, which it was his duty to do as marshal of the United States, and if in doing that act he did no more than what was necessary and proper for him to do, he cannot be guilty of a crime under the law of the State of California. ${ }^{162}$

This is the font of Supremacy Clause immunity.

Before considering how to apply Neagle's articulation of Supremacy Clause immunity, two threshold points bear emphasizing, each of which was anticipated above in Part II. First, recall that although the due process requirement of fair warning applies to all criminal defendants, it does not specify the relevant body of law to which one must look for the requisite warning. In cases like Horiuchi and Neagle, for example, is the officer obliged to consider state criminal law at all before acting? If so, then he surely had ample warning that by shooting another person he risked criminal prosecution. But if not, then the analysis looks only to federal law, and asks only whether the officer exceeded his federal authority to an intolerable extent. Needless to say, much turns on this threshold question.

The fair warning requirement itself does not answer this question, but Neagle does. Specifically, it makes clear that entitlement to Supremacy Clause immunity is to be ascertained by looking only at federal law. The Court considered whether Neagle "was authorized to do [what he did] by the law of the United States," whether "it was his duty to do [it] as marshal of the United States," and whether "in doing that act he did no more than what was necessary and proper for him to do."163 In any case where the answer to those questions is yes, the Court concluded, the officer "cannot be guilty of a crime under the law[s] of [a] State." 164 Three decades later, the Court reiterated this point in Johnson v. Maryland ${ }^{165}$ Recalling Neagle, Justice Holmes's opinion for the Court stressed that "even the most unquestionable and most universally applicable of state laws, such as those concerning murder, will not be allowed to control the conduct of a marshal of the United States acting under and in pursuance of the laws of the United

161. For a discussion of the historical background to the case, see PAUL KENS, JUSTICE

STEPHEN FIELD: SHAPING LIBERTY FROM THE GOLD RUSH TO THE GILDED AGE 276-83 (1997).
162. Neagle, 135 U.S. at 75 .

163. Id.; see also id. at 58 (looking only to whether "it was the duty of Neagle, under the circumstances, a duty which could only arise under the laws of the United States, to defend Mr. Justice Field from a murderous attack upon him").

164. Id. at 75 .

165. 254 U.S. 51 (1920). 
States." ${ }^{166}$ In short, a federal officer's entitlement to immunity from state criminal prosecution does not depend on an assessment of his conduct under state law. When discharging his federal duties, an officer need only ascertain (with what degree of accuracy we will discuss below) that his actions fall within his federal authority.

This rule serves both of the principal federal interests underlying Supremacy Clause immunity. ${ }^{167}$ First, it reflects the intolerable burden that federal officers would face if, before performing their official duties, they were required to review the law of the particular jurisdiction in which they happened to be acting. The specter of federal officers being subject to fifty different standards of conduct depending on where their duties take them underscores the potentially paralyzing effect of such a requirement.

Admittedly, not all federal officers have jobs that take them to all parts of the country the way Agent Horiuchi's did. But even where a federal officer works exclusively in a single State with whose laws he is perfectly familiar, a second - and in many ways more important-federal interest is served by not requiring the officer to consult state law before discharging his federal duties. This is the interest at work in $\mathrm{McCulloch}$ and like casesthe interest in protecting federal law and policy from interference by conflicting state law. ${ }^{168}$ At bottom, this interest reflects the principle of federal supremacy embodied in the Supremacy Clause itself: The validity of federal law does not depend on its conformity with state law; state laws that conflict with federal law are preempted. In this sense, there is no need for a federal officer to determine the legality of his conduct under state law. If state law prohibits conduct that the officer's federal duties require or authorize, it is preempted to the extent of that conflict. ${ }^{169}$

The second threshold point about Supremacy Clause immunity goes to the required specificity of the federal law that authorizes the officer's actions. In general, of course, Congress can always pass specific legislation granting federal officers particular powers. Neagle, for example, would

166. Id. at 56-57; see also Ohio v. Thomas, 173 U.S. 276, 283 (1899) (“[W]hen discharging [their] duties under Federal authority pursuant to and by virtue of valid Federal laws, [federal officers] are not subject to arrest or other liability under the laws of the State in which their duties are performed.").

167. See supra notes $118-119$ and accompanying text.

168. The Court explained:

[N]o principle [of state power] ... can be admissible, which would defeat the legitimate operations of a supreme government. It is of the very essence of supremacy to remove all obstacles to its action within its own sphere, and to so modify every power vested in subordinate governments, as to exempt its own operations from their own influence.

McCulloch v. Maryland, 17 U.S. (4 Wheat.) 316, 427 (1819).

169. See Geier v. Am. Honda Motor Co., 529 U.S. 861, 873 (2000) (explaining that under conflict preemption, state law is displaced to the extent it "stands as an obstacle to the accomplishment and execution of the full purposes and objectives of Congress"' (quoting Hines v. Davidowitz, 312 U.S. 52, 67 (1941))). 
have been an easy case had Congress expressly authorized the use of deadly force to protect federal judges from apparent attack. ${ }^{170}$ But most cases involving assertions of Supremacy Clause immunity arise in the absence of such specific legislative guidance, and the Neagle decision is premised in large measure on the view that no legislation expressly governed the circumstances there at issue. ${ }^{171}$ How should the analysis proceed in such cases? As we noted in our earlier discussion of preemption and McCulloch, when a State attempts to regulate federal instrumentalities or agents directly, its laws may be preempted even in the absence of a specific federal statute with which the state law directly conflicts. ${ }^{172}$ Neagle makes clear that the same is true in cases involving assertions of Supremacy Clause immunity.

The case began, after all, when Neagle, who was being detained on state murder charges after killing Justice Field's supposed assailant, filed a petition for a writ of habeas corpus in federal court. He invoked a federal statute authorizing habeas relief for prisoners held "'in custody for an act done or omitted in pursuance of a law of the United States.",173 California (through the sheriff to whom the writ was directed) argued that "there exists no statute authorizing any such protection as that which Neagle was instructed to give Judge Field in the present case," and thus that habeas relief was unavailable. ${ }^{174}$ The Court conceded California's premise but not its conclusion:

It is not supposed that any special act of Congress exists which authorizes the marshals or deputy marshals of the United States in express terms to accompany the judges of the Supreme Court through their circuits, and act as a body-guard to them, to defend them against malicious assaults against their persons. But we are of

170. For a discussion of whether the Constitution imposes any limits on what Congress could expressly do in this area, see infra Part V.

171. In re Neagle, 135 U.S. 1, 63 (1890) ("The legislative branch of the government can only protect the judicial officers by the enactment of laws for that purpose, and [this case] assumes that no such law has been passed by Congress."). Later in the opinion, the Court suggested that there was "positive law investing the marshals and their deputies with powers which not only justify what Marshal Neagle did in this matter, but which imposed it upon him as a duty." Id. at 68. Specifically, the Court cited a federal statute providing that federal marshals "shall have, in each State, the same powers, in executing the laws of the United States, as the sheriffs and their deputies in such State may have, by law, in executing the laws thereof."' Id. (quoting REV. STAT. $\S 788(1875)$ ). But even that statutory provision did not specifically exempt federal marshals from the constraints of state criminal law, which presumably would apply to state law enforcement officers. Thus, the scope of Neagle's permissible authority was not definitively answered by statute; the analysis ultimately depended on deciding how much discretionary leeway should be accorded to him in order to enable him to discharge his federal duties effectively.

172. See supra notes 104-115 and accompanying text.

173. Neagle, 135 U.S. at 40-41 (quoting REV. STAT. § 753).

174. Id. at 58 ; see also id. ("It is urged ... that the language of section 753 of the Revised Statutes ... makes it necessary that upon this occasion it should be shown that the act for which Neagle is imprisoned was done by virtue of an act of Congress."). 
opinion that this view of the [habeas] statute is an unwarranted restriction of the meaning of a law designed to extend in a liberal manner the benefit of the writ of habeas corpus to persons imprisoned for the performance of their duty. And we are satisfied that if it was the duty of Neagle, under the circumstances, a duty which could only arise under the laws of the United States, to defend Mr. Justice Field from a murderous attack upon him, he brings himself within the meaning of the section [of the habeas statute] we have recited....

In the view we take of the Constitution of the United States, any obligation fairly and properly inferrible from that instrument, or any duty of the marshal to be derived from the general scope of his duties under the laws of the United States, is "a law" within the meaning of th[e] phrase [in the habeas statute]. ${ }^{175}$

The question in Neagle was not, therefore, whether a particular federal statute authorized the marshal to shoot Justice Field's assailant. Rather, the question was whether the use of deadly force in the circumstances was reasonably understood to be within "the general scope" of Neagle's duties. The Court concluded that it was. Although the Court reached that conclusion with reference to the terms of the federal habeas statute there at issue, more broadly it also clarified that state law is displaced whenever it imposes intolerable burdens on a federal officer's attempts to protect federal interests or to execute federal law, even in the absence of a federal statute specifically authorizing his conduct. ${ }^{176}$

The logic underlying this position is one of governmental necessity implicit in the constitutional order. ${ }^{177}$ The federal government relies on its officers to implement federal law and policy; federal officers' authority to carry out federal objectives is inherent in the federal government itself, and necessary to its proper functioning. ${ }^{178}$ Neagle located part of that authority

175. Id. at 58-59 (emphasis added).

176. Id. at 75 .

177. See Ex parte Siebold, 100 U.S. 371, 395 (1879) ("We hold it to be an incontrovertible principle, that the government of the United States may, by means of physical force, exercised through its official agents, execute on every foot of American soil the powers and functions that belong to it. This necessarily involves the power to command obedience to its laws, and hence the power to keep the peace to that extent."); Tennessee v. Davis, 100 U.S. 257, 263 (1880) ("[I]f the general government is powerless to interfere at once for th[e] protection [of its officers]... the operations of the general government may at any time be arrested at the will of one of its members."); see also Tribe, supra note 98, at 700 (describing federal immunity from direct state regulation as "a residual immunity [that] may ... be inferred from the plan of the Constitution").

178. Neagle's use of the phrase "necessary and proper," 135 U.S. at 75, evokes the Constitution's Necessary and Proper Clause, U.S. CONST. art. I, $\S 8$, cl. 18 (granting Congress the power to "make all Laws which shall be necessary and proper for carrying into Execution" the powers elsewhere conferred by the Constitution). We think this is a useful parallel, particularly because the Court has been very permissive in describing the means-ends relationship entailed in the Necessary and Proper Clause. See, e.g., McCulloch v. Maryland, 17 U.S. (4 Wheat.) 316,413 
in the President's constitutional duty to "take Care that the Laws be faithfully executed." ${ }^{179}$ Federal law enforcement officers help the President discharge that duty. As Neagle rhetorically asked:

Is this duty limited to the enforcement of acts of Congress or of treaties of the United States according to their express terms, or does it include the rights, duties and obligations growing out of the Constitution itself, our international relations, and all the protection implied by the nature of the government under the Constitution? ${ }^{180}$

Supremacy Clause immunity takes the latter approach. That is, it provides that unless Congress expressly specifies the extent to which the federal government and its agents may be subject to state law, the default presumption is in favor of enough immunity to ensure that the federal government operates smoothly and effectively.

In sum, Neagle answered two threshold questions about Supremacy Clause immunity. First, the analysis looks at the propriety of the officer's action with respect only to federal law, not state law. Second, the analysis need not train on any particular federal enactment, but rather examines whether the state law at issue threatens to interfere with the federal government's inherent interest in the effective implementation of federal policy through its agents. With these points in mind, we can turn to an examination of the proper scope of Supremacy Clause immunity.

\section{Competing Visions of Supremacy Clause Immunity}

Courts have generally regarded Neagle as establishing a two-prong test for immunity. First, was the officer performing an act that federal law authorized him to perform? ${ }^{181}$ Second, were his actions necessary and proper to fulfilling his federal duties? ${ }^{182}$ This test is much easier to recite than to apply. The first prong, for example, might demand that the federal officer have authority to perform the specific act in question, or it might require only that the officer's actions fall within the general scope of his duties. And the second prong might be read to mean that the officer's actions must have been actually necessary and proper to fulfilling his

(1819) (indicating that the word "necessary" in the Necessary and Proper Clause authorizes legislation that Congress deems "convenient, or useful," to the exercise of an enumerated power). Just as a law need not be shown to be strictly "necessary" to the exercise of an enumerated power in order to pass muster under the Necessary and Proper Clause, the application of Supremacy Clause immunity in a given case should not depend on whether it is literally necessary to effectuate a federal law or policy.

179. U.S. CONST. art. II, $\$ 3$.

180. 135 U.S. at 64.

181. See, e.g., Kentucky v. Long, 837 F.2d 727, 744 (6th Cir. 1988).

182. See id. 
federal duties, or it might be satisfied so long as the federal officer reasonably believed he was doing what was necessary and proper, even if his actions in fact were improper. That is, immunity might go only as far as the letter of the officer's federal authority. Alternatively, the federal interest in enabling the officer to discharge his duties effectively might extend the immunity to cover all conduct that the officer reasonably-even if ultimately incorrectly-thinks is within his authority.

As evidence of the different possibilities in this area, consider the various positions articulated in the Horiuchi case. The briefs filed in the case illustrate quite nicely at least some of the available views. On one end of the spectrum was Idaho, whose brief, long on colorful metaphor, characterized the assertion of Supremacy Clause immunity as a claim that the United States "is the king and [Horiuchi] is its Sheriff of Nottingham, who may do no wrong when he does its bidding." 183 Idaho's principal argument was that the very idea of immunity in this context is "an archaic anomaly" unfit for American democracy. ${ }^{184}$ Alternatively, Idaho contended that to the extent Supremacy Clause immunity exists at all, it should not shield federal officers whose actions were objectively unreasonable. On this view, Supremacy Clause immunity directly intrudes upon the State's core police power, and must not be tolerated any more than is absolutely necessary. There can be no legitimate federal interest in immunizing objectively unreasonable conduct; Horiuchi, Idaho argued, had acted unreasonably in firing the shot that killed Vicki Weaver.

At the opposite end of the spectrum was a group of former United States Attorneys General who filed a brief as amici curiae. ${ }^{185}$ They took the position that federal officers should be entitled to complete immunity from state charges for any and all acts within the scope of their federal authority. On this view, while a federal officer might be subject to federal criminal or civil penalties for his actions, he should be immune from state prosecution provided he was acting within the broad scope of his federal employment. This argument was premised on a broad, categorical assessment of the circumstances in which state law interferes with federal interests in this area. The Attorneys General argued that permitting state law to play any role in cases like Horiuchi would compromise the integrity of FBI agents' split-second decisionmaking, and thus frustrate the compelling federal interest in enabling the FBI to do its job effectively. Moreover, subjecting federal officers to the constraints of state law risked creating an

183. Plaintiff-Appellant's Opening Brief at 58, Idaho v. Horiuchi, 253 F.3d 359 (9th Cir. 2001) (No. 98-30149).

184. Id.

185. The brief was filed on behalf of William Bar, Griffin Bell, Benjamin Civiletti, Richard Thomburgh, and William Webster. See Brief of Amici Curiae Hon. William P. Barr et al., Idaho v. Horiuchi, 266 F.3d 979 (9th Cir. 2001) (No. 98-30149). 
unmanageable patchwork of fifty different standards of conduct, depending on where in the country an officer's job took him. Because of the threat that such variation would pose to the strong federal interest in effective and consistent execution of federal policy, the Attorneys General argued that no state role was appropriate in cases like Horiuchi.

The United States, and Horiuchi himself, took a middle position. They argued that federal officers acting within the scope of their employment are immune from state prosecution for any action they take that they reasonably believe is necessary and proper to the performance of their federal functions. On one hand, that standard affords considerable deference to the federal officer: It grants immunity unless no reasonable officer could have concluded that the actions were necessary and proper to the performance of his federal functions. ${ }^{186}$ On the other hand, this position certainly leaves room for state prosecution when federal officers either act completely outside the scope of their employment or take measures so extreme that no reasonable officer could have deemed them appropriate. In Horiuchi's case, the United States argued that even if a court were to determine ex post that he should not have fired the second shot, it would still have been reasonable at the time for him to have concluded that, in light of the extreme danger of the situation and the lightning pace of events, the shot was warranted. In those circumstances, the United States argued, prosecuting Horiuchi for his actions would risk chilling the important discretionary judgments that federal officers must sometimes make in the course of discharging their federal duties.

\section{Equating Supremacy Clause Immunity with Qualified Immunity}

Which of these formulations best captures the doctrinal foundations and policy aims of Supremacy Clause immunity? In Horiuchi, the position of the United States essentially gave Supremacy Clause immunity the same scope as qualified immunity in the Bivens and $\S 1983$ contexts. ${ }^{187}$ We think

186. Considerable lower court precedent supports this standard. In Clifton v. Cox, for example, the Ninth Circuit explained that immunity depends on "whether the official employs means which he cannot honestly consider reasonable in discharging his duties or otherwise acts out of malice or with some criminal intent." 549 F.2d 722, 728 (9th Cir. 1977). "Proper application of this standard," the court explained, "does not require a petitioner to show that his action was in fact necessary or in retrospect justifiable, only that he reasonably thought it to be." Id: see also In re McShane, 235 F. Supp. 262, 273 (N.D. Miss. 1964) (holding that federal officers are to be denied immunity from state prosecution only if they "employ means which they cannot honestly consider reasonable in discharging their duties or who otherwise act out of malice or with some criminal intent" (emphasis omitted)); United States v. Lipsett, 156 F. 65, 71 (W.D. Mich. 1907) (finding a federal officer "not liable to prosecution in the state court from the fact that from misinformation or lack of good judgment he transcended his authority").

187. Horiuchi himself attempted to assert qualified immunity in a Bivens action that Kevin Harris filed against him and other federal officers. Construing all pleaded facts in Harris's favor 
this equation is appropriate. Two converging rationales support our conclusion.

Fair Warning. First, recall that in Lanier, the Supreme Court characterized the due process right to fair warning as coextensive with qualified immunity. ${ }^{188}$ Just as state officers facing criminal prosecution under federal statutes like $\$ 242$ can invoke the fair warning requirement to raise a kind of qualified immunity defense to their prosecution, federal agents like Horiuchi should be able to raise the same kind of fair warning defense against state criminal prosecution.

To be sure, the fair warning analysis keys on different issues in different contexts. When an officer facing criminal charges under $\S 242$ raises the fair warning defense, the issue is typically whether it was sufficiently clear at the time that the officer's conduct was not only harmful but also violative of the victim's federal rights. ${ }^{189}$ In cases like Horiuchi, however, the question on the liability side is not whether the conduct offends the national Constitution but whether it violates state criminal law. And absent considerations of immunity, the answer in a case like Horiuchi is clearly yes. Horiuchi did not attempt to argue, for example, that a private citizen would have been justified in firing the shot that killed Vicki Weaver. But as we have seen, Supremacy Clause immunity does not look to what a federal officer should reasonably have known about state law. ${ }^{190}$ Instead, the issue for fair warning purposes is whether it was clear at the time Horiuchi fired the shot that he did not have proper federal authority to do so. If the answer is yes, then Horiuchi had fair warning of the criminality of his act; otherwise, he lacked such warning and may not be prosecuted for it.

This analysis mirrors the qualified immunity analysis that would apply if the officer were sued under Bivens. In both cases, the question is whether the officer had sufficient notice that his conduct was outside the scope of his federal authority. In the Bivens context, the analysis looks to whether it was "clearly established at the time an action occurred"191 that the offending conduct was unconstitutional or otherwise contrary to federal law. If so, then the officer could not reasonably have thought he was authorized to do what he did. In the Supremacy Clause immunity context, the question is whether, in light of the laws, regulations, and policies supplying the officer with his authority, it was clear that he lacked the

for purposes of a motion to dismiss, the Ninth Circuit concluded that Horiuchi could not avoid trial. See Harris v. Roderick, 126 F.3d 1189, 1205 (9th Cir. 1997). The court did not, however, rule out qualified immunity at summary judgment or later. See Horiuchi, 253 F.3d at 389 n.10 (Hawkins, J., dissenting) (discussing Harris). We express no opinion on the correctness of the Harris decision.

188. See supra notes 58-61 and accompanying text.

189. See, e.g., United States v. Lanier, 520 U.S. 259 (1997).

190. See supra notes 163-169 and accompanying text.

191. See Harlow v. Fitzgerald, 457 U.S. 800, 818 (1982). 
authority to do what he did. The clarity in the former context is with respect to the law the officer is charged with violating; in the latter, it is with respect to the law investing him with authority. But the analyses complement each other because any conduct that violates clearly established constitutional law cannot reasonably be thought to be within the scope of the officer's authority.

The fair warning requirement thus provides a kind of syllogistic rationale for equating Supremacy Clause immunity. As described above, ${ }^{192}$ fair warning is constitutionally mandated. Under Lanier, fair warning is coextensive with qualified immunity. Hence, equating Supremacy Clause immunity with qualified immunity satisfies the Constitution's demand for fair warning.

Preemption. Second, equating Supremacy Clause immunity with qualified immunity finds support in preemption doctrine, and especially in the federal interests served by preemption. As previously noted, ${ }^{193}$ the general rule in cases where a State attempts to regulate the federal government directly is that state law is preempted to the extent it conflicts with the effectuation of federal interests and policy. This principle can explain the law of qualified immunity.

A federal officer's qualified immunity in a Bivens or similar action serves and reflects a federal interest. Specifically, by according federal officers qualified immunity, the federal courts (and implicitly Congress insofar as it has chosen not to abolish qualified immunity) respect the important federal interest in protecting against the "risk that fear of personal monetary liability and harassing litigation will unduly inhibit officials in the discharge of their duties." " 94 This is not just a personal interest of the officer, but an institutional interest of the government: The federal interest in the integrity of federal law includes an interest in the ability of federal officers to enforce the law free from state interference. Principles of implied conflict preemption suggest that the States may not intrude upon that interest. Qualified immunity prevents them from doing so.

The federal government has the same interest in shielding federal officers from state criminal prosecutions. Extending Supremacy Clause immunity to the full reach of qualified immunity achieves that purpose, and enjoys equal support from preemption doctrine.

Should Supremacy Clause immunity extend even further? In Horiuchi, the former Attorneys General argued that it should, on the theory that any application of state criminal law to federal officers for their on-the-job conduct is an intolerable interference with federal interests. Although this

192. See supra notes 51-64 and accompanying text.

193. See supra Subsection II.B.2.

194. Anderson v. Creighton, 483 U.S. 635,638 (1987) (citation omitted). 
broader form of immunity may seem attractive as a policy matter-it would completely negate the specter of fifty different States imposing fifty potentially different standards of conduct-we find it ultimately unpersuasive. Under the now-familiar test for qualified immunity, an officer may be held civilly liable only if he could not reasonably have thought he was justified in his actions. ${ }^{195}$ If a federal officer fails in his assertion of qualified immunity in a Bivens action, it follows a fortiori that he could not reasonably have thought his conduct was authorized by federal law. In that circumstance, the federal officer stands in the same position as the recklessly driving postal worker, ${ }^{196}$ and it is difficult to perceive a legitimate federal interest in precluding the routine application of state law against the officer. Confining Supremacy Clause immunity to the scope of qualified immunity thus reinforces the idea that federal supremacyincluding the immunity afforded by the Supremacy Clause-enables federal law to trump state law only insofar as the two actually conflict. ${ }^{197}$

\section{State Civil Law}

For purposes of comparison, consider cases outside the criminal context and thus removed from the due process dimensions of the fair warning requirement. We discuss two areas of state law in this regard: tort law, and state legal ethics rules.

May federal officers be sued for violating state tort law while discharging their federal duties? Under current law, the answer is generally no. In 1988, Congress amended the Federal Tort Claims Act (FTCA) to make it the exclusive remedy for nonconstitutional torts committed by federal officials in the course of their official duties. ${ }^{198}$ The FTCA's preemptive force is triggered by the Attorney General's certification that the federal employee being sued was acting within the scope of his

195. See Harlow, 457 U.S. at 818.

196. See supra notes 153-154 and accompanying text.

197. See Nat'l Bank v. Kentucky, 76 U.S. (9 Wall.) 353, 362 (1869). A parallel may be found in 42 U.S.C. $\$ 1988(2000)$, which instructs federal courts on what law to apply in civil rights cases, and in particular to fill gaps in federal statutes with compatible state law. The provision directs in part that where federal laws "are not adapted to the object [of protecting federal civil rights], or are deficient in the provisions necessary to fumish suitable remedies and punish offenses against law," state law shall apply "so far as the same is not inconsistent with the Constitution and laws of the United States." Id. § 1988(a) (emphasis added); see also Theodore Eisenberg, State Law in Federal Civil Rights Cases: The Proper Scope of Section 1988, $128 \mathrm{U}$. PA. L. REV. 499, 528-29 (1980) (persuasively describing an application of $\S 1988$ 's "inconsistency" provision that closely mirrors the approach to Supremacy Clause immunity proposed here).

198. See Federal Employees Liability Reform and Tort Compensation Act of 1988, Pub. L. No. 100-694, 102 Stat. 4563 (amending 28 U.S.C. $\$ 2679$ (b), (d) (2000)). The exemption for alleged violations of constitutional rights is found at 28 U.S.C. $\$ 2679$ (b)(2)(A). Allegations of such violations remain cognizable, at least in certain circumstances, in Bivens actions. 
employment. ${ }^{199}$ This statutory arrangement by itself confirms that the extent to which state law may constrain federal officers is ultimately up to Congress. $^{200}$ Although tort law is certainly an area of traditional state power, the application of that law to the federal government or its agents is not an aspect of that traditional power. Rather, direct state regulation of the federal government is a creature of congressional consent; with the amendments to the FTCA, Congress withdrew that consent for nonconstitutional torts.

But what if, as in the criminal area, Congress does not expressly specify the degree to which federal officers may be subject to state law? State tort cases predating the amendments to the FTCA confirm that in the absence of such express congressional action, implied conflict preemption is the appropriate analytical approach, just as in criminal cases like Horiuchi. In Barr v. Matteo, for example, the Supreme Court held a federal official immune from a state action for libel. ${ }^{201}$ In reaching that conclusion, the Court's plurality opinion concluded that the defendant had an "absolute immunity" from the suit because her actions were "within the outer perimeter of [her] line of duty."202 This reference to absolute immunity created some confusion in later cases, but the Court ultimately confirmed that Barr did not "purport[] to abolish the liability of federal officers for actions manifestly beyond their line of duty." read as providing qualified immunity for actions reasonably within the scope of a federal official's duties.

To be sure, one could describe the Barr standard as one of absolute immunity to the extent that the official could reasonably have believed her conduct was within the "outer perimeter of [her] line of duty."204 But at that point the difference is merely semantic; the critical point is that to the extent that state suits against federal officials were permitted prior to the 1988 amendments to the FTCA, the immunity analysis entailed essentially the same kind of inquiry we have described in addressing Supremacy Clause immunity. In both contexts, the key question is whether the federal official's conduct could fairly be said to be within her federal duties. ${ }^{205}$ If so, then immunity attaches because subjecting the official to civil suit

199. See 28 U.S.C. $\$ 2679$ (d).

200. Cf. Westfall v. Erwin, 484 U.S. 292, 295 (1988) (holding that official immunity from state civil liability is "to be formulated by the courts in the absence of legislative action by Congress"' (quoting Howard v. Lyons, 360 U.S. 593, 597 (1959) (plurality opinion)) (cmphasis added)).

201. 360 U.S. 564, 564 (1959) (plurality opinion).

202. Id. at 575 .

203. Butz v. Economou, 438 U.S. 478, 495 (1978).

204. 360 U.S. at 575.

205. As a federal court of appeals described the immunity standard in the civil context, "[I]t is only necessary that the action bear some reasonable relation to and connection with the dutics and responsibilities of the official." Scherer v. Brennan, 379 F.2d 609, 611 (7th Cir. 1967). 
would interfere with the federal interest in enabling the official to discharge her duties effectively. But if not, then there is no real federal interest in shielding the official's clearly ultra vires actions from liability, and immunity does not attach.

Moving to our second example, consider state ethics rules governing the practice of law. In the late 1980 s, a controversy arose between the Justice Department and state bar organizations over the extent to which state ethics rules governed federal prosecutors. ${ }^{206}$ The dispute was particularly acute over issues like prosecutorial contact with represented parties outside the presence of counsel. Federal regulations imposed certain restrictions on such communications, but did not bar them outright. ${ }^{207}$ They were, however, prohibited by many States' ethics rules. ${ }^{208}$ If a federal prosecutor violated a state rule in this area, could he be subject to state disciplinary proceedings? Could the State (or state bar association) prohibit him from practicing law in the State? Could it fine him?

Two successive Attorneys General answered those questions in the negative. In 1989, Attorney General Thornburgh announced in an internal memorandum that Justice Department attorneys were exempt from state ethics rules. ${ }^{209}$ In 1994, Attorney General Reno promulgated formal Justice Department regulations generally adhering to that position, ${ }^{210}$ though also providing that States could impose their own sanctions on federal attorneys who engaged in "willful violation[s]" of the federal rules covering communications with represented persons. ${ }^{211}$ In 1998, however, Congress resolved the issue more conclusively-and, in contrast to the FTCA, more favorably for the States--by passing the Citizens Protection Act (CPA). ${ }^{212}$ The Act provides, in pertinent part, that an attorney for the federal government "shall be subject to State laws and rules...governing attorneys in each State where such attorney engages in that attorney's

206. See, e.g., Roger C. Cramton \& Lisa K. Udell, State Ethics Rules and Federal Prosecutors: The Controversies over the Anti-Contact and Subpoena Rules, 53 U. PITT. L. REV. 291 (1992); Rory K. Little, Who Should Regulate the Ethics of Federal Prosecutors?, 65 ForDHAM L. REV. 355, 406-10 (1996); Fred C. Zacharias \& Bruce A. Green, The Uniqueness of Federal Prosecutors, 88 GEO. L.J. 207, 212-14 (2000).

207. See, e.g., Communications with Represented Persons, 59 Fed. Reg. 39,910, 39,930

(Aug. 4, 1994) (formerly codified at 28 C.F.R. $\S \S 77.8-77.9$ (1995)).

208. See Zacharias \& Green, supra note 206 , at 212.

209. See In re Doe, 801 F. Supp. 478, 489 (D.N.M. 1992) (reprinting Memorandum from Dick Thomburgh, Attorney General, to All Justice Department Litigators (June 8, 1989)); see also Dick Thornburgh, Ethics and the Attorney General: The Attorney General Responds, 74 JUDICATURE 290 (1991) (discussing and providing justifications for the Thomburgh Memorandum).

210. See Communications with Represented Persons, 59 Fed. Reg. at 39,931 (formerly codified at 28 C.F.R. $\$ 77.12$ ).

211. Id.

212. 28 U.S.C. $§ 530 B$ (2000); see also 144 CONG. REC. E301 (daily ed. Mar. 5, 1998) (statement of Rep. McDade) (introducing the precursor bill to 28 U.S.C. $\S 530 \mathrm{~B}$ as the "Citizens Protection Act"). 
duties, to the same extent and in the same manner as other attorneys in that State." ${ }^{213}$ That is, Congress put federal attorneys on the same footing as all other attorneys practicing in a given jurisdiction. ${ }^{214}$

This history, like that of the FTCA and the cases predating its amendment, confirms the two principal points of our thesis. First, Congress is the ultimate arbiter of the extent to which federal officers may be subject to state law. In the CPA, Congress made a decision quite unlike its decision in the FTCA: Rather than granting federal officers broad immunity from state law, it subjected federal attorneys to the full force of the rules governing attorney conduct in the States where they act. This presumably includes all disciplinary proceedings and penalties to which an attorney may be subject for violating a State's rules. The CPA's apparent withdrawal of all federal immunity in this area, like the FTCA's broad conferral of immunity in the areas to which it applies, is well within Congress's discretion.

Second, prior to the CPA's passage, the Justice Department's regulations permitted state law to apply in instances where it clearly did not conflict with federal standards. ${ }^{215}$ This attentiveness to federal-state conflict comports with our approach to Supremacy Clause immunity in the absence of express congressional instruction. In that context, as we have argued, a measure of officer immunity akin to qualified immunity is necessary to ensure that federal law and policy is effectuated free from state interference. Until Congress decided in the CPA to make compliance with state rules a matter of federal policy, the Justice Department's regulations pursued the same objective animating our approach to Supremacy Clause immunity: ensuring that state law considerations did not chill or otherwise compromise federal prosecutors' reasonable pursuit of federal aims. ${ }^{216}$

213. 28 U.S.C. $\$ 530 \mathrm{~B}(\mathrm{a})$.

214. See Mendoza Toro v. Gil, 110 F. Supp. 2d 28, 37 n.3 (D.P.R. 2000) (noting that under the CPA, "[a]ttorneys for the federal government are ... subject to local laws governing the conduct of attorneys").

215. See Communications with Represented Persons, 59 Fed. Reg. at 39,931 (formerly codified at 28 C.F.R. $\$ 77.12$ ).

216. As the Justice Department's commentary on the rule explained:

A primary purpose for this regulation is to remove the substantial burden on federal law enforcement caused by uncertainty as to what constitutes appropriate conduct by Department attorneys. This uncertainty would not be removed were it left to the various state and federal district courts to interpret these rules and determine on their own whether they had been violated in any particular case. For this reason, the Department believes that it is necessary that it retain exclusive authority to determine whether one of its lawyers has breached these rules, with the important proviso that, when there is a finding of a willful violation, a state disciplinary authority may also impose sanctions. Id. at 39,927 . 


\section{State Rights of Action To Enforce the Constitution: "Converse-1983"}

The discussion thus far has examined the extent to which States may subject federal officers to the standards of conduct contained in state law. In Horiuchi, however, Idaho attempted to bolster its argument with the suggestion that to accord Horiuchi immunity in that case would be to insulate him not only from state criminal law, but from the Constitution as well. That is, Idaho asserted that Horiuchi's conduct was not only illegal under Idaho law but also contrary to the national Constitution. ${ }^{217}$ The contention was mostly rhetorical flourish in Horiuchi, but it raises an interesting related question worth considering here: Even if there are valid limits on a State's power to subject federal officers to substantive standards of conduct based on state law, may a State provide a cause of action against federal officers for violating federal constitutional standards? Section 1983 provides a federal cause of action against state actors who act unconstitutionally; may States enact the mirror image? $?^{218}$

Akhil Amar argues that the answer is yes. Specifically, he proposes that States enact "converse-1983" statutes providing damages remedies for violations of the federal Constitution by federal officers. ${ }^{219}$ As Amar puts it, "States should enact converse-1983 laws because doing so is in the highest tradition of supporting the federal Constitution and vindicating its implicit remedial scheme, which so heavily depends on each government policing the other to vindicate citizen rights., ${ }^{, 220}$

Against the objection that this sort of statute would violate the Supremacy Clause by elevating state law over federal law, Amar convincingly points out that converse-1983 statutes in fact would enforce the Supremacy Clause by ensuring that federal action complies with the Constitution. ${ }^{221}$ The Constitution does not commit its enforcement only to the federal government; rather, the Supremacy Clause confirms that both the States and the federal government are obliged to enforce the Constitution as the supreme law of the land. Amar argues that States should therefore take a more active role in ensuring that the Constitution is enforced against the federal government. Amar does readily concede that converse-1983 actions would be removable to federal court because of the

217. See, e.g., Transcript of Motions Hearing en Banc at 23, Idaho v. Horiuchi, 215 F.3d 986 (9th Cir. 2000) (No. 98-30149) (suggesting that the FBI rules of engagement authorizing Agent Horiuchi to shoot armed men outside the Weaver house were "unconstitutional").

218. 42 U.S.C. $\S 1983(2000)$.

219. See Amar, Sovereignty and Federalism, supra note 19, at 1512-19; Amar, Questions and Answers, supra note 19.

220. Amar, Questions and Answers, supra note 19, at 176.

221. Id. at 163 . 
constitutional questions and clear federal interests involved. ${ }^{222} \mathrm{He}$ stresses, however, that their utility would be to provide an effective remedy for constitutional violations by federal officers, regardless of venue. ${ }^{223}$

Without regard to their wisdom as a policy matter, we are inclined to agree that at least some kinds of converse-1983 laws are constitutional. As Amar points out, there is notable historical precedent supporting this conclusion. In the intriguing case of United States v. Lee, ${ }^{224}$ the Supreme Court held that the federal government's foreclosure on property owned by the son of Robert E. Lee violated the Fifth Amendment's Due Process and Takings Clauses. Crucially, Lee relied on a state cause of action to sue in federal court and to seek redress for the government's unconstitutional conduct. ${ }^{225}$ Lee thus suggests that States today could provide statutory rights of action to remedy unconstitutional conduct by federal officers.

Still, as long as Bivens remains in place and converse-1983 actions would be removed to federal court anyway, one might legitimately ask what purpose a converse-1983 statute would serve. Would it not be simply duplicative of Bivens? Amar's principal answer is that converse-1983 statutes could provide a more meaningful and effective remedy for constitutional violations because they "might" not need to be encumbered by the "various zones of immunity" that apply in Bivens actions. ${ }^{226}$ Rightly observing that the Court has never held qualified and other forms of officer immunity to be constitutionally compelled, Amar suggests that States could choose instead to provide "full remedies for violations of constitutional rights" by authorizing "the maximum amount of recovery that is permissible under the federal Constitution." 227

Amar concedes that Congress could preempt state converse-1983 laws in order to establish uniform standards of conduct for federal officers across the country. ${ }^{228} \mathrm{He}$ insists, however, that "if Congress seeks to oust state law here, Congress must itself provide a federal remedy at least as generous as the most generous state remedy Congress seeks to preempt." 229 That is, state converse-1983 statutes may not simply be deemed preempted to the extent they are inconsistent with federal law or policy. Rather, they can

222. Id. at $163-67$.

223. Id. at 166 ("At its core, converse-1983 is not about state court judicial jurisdiction; it is about state law as a remedy applicable in all courts, state and federal.").

224. 106 U.S. 196 (1882).

225. See Amar, Sovereignty and Federalism, supra note 19, at 1512 (discussing Lee).

226. Amar, Questions and Answers, supra note 19, at 174.

227. Id. at 175-76. Amar does not fully explain what the maximum might be, though he acknowledges that a damages award must not be "so punitive... as to amount to a "tax masquerading as a remedy," id. at 179, or otherwise "overcompensatory," Amar, Sovereignty and Federalism, supra note 19, at 1519 n.364.

228. Amar, Questions and Answers, supra note 19, at 179 ("There is a legitimate federal interest in uniformity, eliminating a patchwork of state law remedies so that a federal officer's liability will not wildly fluctuate as he moves from state to state ....").

229. $I d$. 
only be displaced by an equally robust federal remedy for the targeted unconstitutional conduct.

We disagree. First, there can be no argument that the Constitution itself requires remedies that are unmodified by officer immunity. If that were the case, then both Bivens and $\S 1983$ would be unconstitutional. True, as we have observed, ${ }^{230}$ qualified immunity is not constitutionally required ${ }^{231}$ But neither is it constitutionally prohibited. Thus, a State that decides to enact a converse-1983 statute without providing for qualified immunity does not implement a constitutional requirement. The State may well conclude that qualified immunity disserves general constitutional values insofar as it causes the victims of some unconstitutional conduct to bear the cost of that conduct, but that is a conclusion based on policy preference, not constitutional command.

Viewed in this light, a converse-1983 statute denying qualified immunity is simply a state law, not an extension of the Constitution itself. As such, it is subject to the Supremacy Clause and the preemption principles that implement it. ${ }^{232}$ Under the general rules of implied conflict preemption, a state law is preempted to the extent it "'stands as an obstacle to the accomplishment and execution of the full purposes and objectives of Congress. ", ${ }^{233}$ Thus, if States were to begin passing strict liability converse1983 statutes, Congress could certainly preempt those laws by codifying Bivens and its qualified immunity component. Unless it were clear that Congress intended its new enactment to establish only a minimum standard of conduct subject to ratcheting up by the States, the converse-1983 laws would be preempted because their denial of qualified immunity would conflict with Congress's judgment that federal officers should be entitled to such immunity. ${ }^{234}$

230. See supra notes $45-50$ and accompanying text.

231. We consider here only state rights of action for damages and other forms of legal and equitable relief. We do not consider, and Amar does not propose, the possibility of what might be called "converse-242" statutes-state laws making it a state criminal offense to violate the federal Constitution. Although we think States could probably enact such laws, we think it is equally clear that, under Lanier, due process principles of fair warning would compel a form of immunity comparable in scope to qualified immunity. See United States v. Lanier, 520 U.S. 259 (1997).

232. Amar combats this point by observing that "Congress enjoys no explicit power to preempt state remedies for unconstitutional federal conduct." Amar, Sovereignty and Federalism, supra note 19 , at 1518 . It is true that the Constitution does not speak of such a power explicitly, but for the reasons discussed in the text we think it is clear that the Supremacy Clause itself adequately provides for the preemption of state laws that conflict with validly enacted federal laws, even when the state law at issue purports to enforce constitutional norms.

233. Geier v. Am. Honda Motor Co., 529 U.S. 861, 873 (2000) (quoting Hines v. Davidowitz, 312 U.S. 52, 67 (1941)).

234. Cf. Pilot Life Ins. Co. v. Dedeaux, 481 U.S. 41, 54 (1987) ("The policy choices reflected in the inclusion of certain remedies and the exclusion of others under the federal scheme would be completely undermined if ERISA-plan participants and beneficiaries were free to obtain remedics under state law that Congress rejected in ERISA."); Avco Corp. v. Acro Lodge No. 735, Int'1 Ass'n of Machinists, 390 U.S. 557, 560-61 (1968) (contending that state law cannot be applied to 
Moreover, we think courts would likely find a converse-1983 statute denying qualified immunity to be preempted even in the absence of a new federal statute codifying the Bivens standard. As we discussed above, ${ }^{235}$ where a State attempts to regulate federal agents directly, the conflict analysis need not be confined to specific federal statutes. Rather, the state law is preempted to the extent it interferes with the effectuation of federal interests or policies more broadly defined. In this context, the preemption analysis asks whether the heightened liability provided under a converse1983 statute conflicts with Bivens or otherwise intrudes too much upon the federal interest in federal officers being able to discharge their duties effectively. We think modern courts would likely find a conflict and thus limit the state statute to authorizing actions essentially duplicative of Bivens itself. To do otherwise would be to forsake the substantial federal interest in protecting the good-faith, discretionary decisions federal officers make in the course of enforcing federal law.

Whether federal officers ought to be able to invoke qualified immunity when sued for allegedly unconstitutional conduct is a difficult policy question. Legitimate arguments can surely be made on either side. But because the Constitution itself clearly does not prohibit qualified immunity, a State's decision to withhold immunity should be subject to preemption if it conflicts with federal law or interferes with federal policy. In that respect, the power of the federal government to create a cause of action to remedy unconstitutional state conduct is not matched by converse state power. Here, as elsewhere in this Article, the underlying point is that the Constitution-especially the Supremacy Clause - does not install federalstate parity when it comes to intersovereign regulation.

\section{AN OBJECTION: SEPARATION OF POWERS AS A SAFEGUARD OF FEDERALISM ${ }^{236}$}

Fine doctrinal points aside, one might object that our view of Supremacy Clause immunity-indeed, of federal officer immunity in generat too readily compromises core state functions. Specifically, one could argue that by according immunity to federal officers even in the absence of federal legislation specifically preempting otherwise applicable state law, Supremacy Clause immunity puts the power to preempt in the hands of individual federal officers. In so doing, it evades the checks on preemption inherent in the federal lawmaking process.

agreements enforceable under section 301 of the federal Labor-Management Relations Act even though federal law did not provide for the injunctive relief available under state law).

235. See supra notes 104-115 and accompanying text.

236. The phrase is Bradford Clark's. See Clark, supra note 76. 
Bradford Clark argues that because the Supremacy Clause refers specifically to "the 'Laws' ... of the United States" as having preemptive force, it "requires adherence to constitutionally prescribed lawmaking procedures in order to displace state law."237 The federal separation of powers, Clark maintains, is thus a safeguard of federalism: State law may not be displaced except by properly enacted federal statutory law. The presumption against preemption is one aspect of this protection. It "ensures that Congress and the President-rather than politically unaccountable judges-make the crucial decision to preempt state law through constitutionally prescribed lawmaking procedures designed to safeguard federalism."238

On this view, one might argue that federal officers should be held immune from state prosecution only where Congress specifically so provides. The "political safeguards of federalism" cannot operate, the argument would go, if the federal legislative process is evaded altogether. And in the absence of such safeguards, the federal courts will have virtually unfettered power to alter the federal-state status quo with immunity doctrines that have not even been ratified by Congress. The same federalism-protecting considerations underlying the presumption against preemption dictate that Congress, not the courts, should decide what, if any, immunity federal officers enjoy from state law..$^{239}$

Although this objection has rhetorical force, Clark does not raise it. Rather, he concedes that McCulloch and later cases provide for the "constitutional preemption of state law that unduly impairs federal functions." 240 By "constitutional preemption," we understand Clark to refer to the idea that the States lack the constitutional authority to regulate the federal government or its agents in a manner that frustrates federal policies or otherwise interferes with federal functions. We read $M c C u l l o c h$ and its progeny similarly. ${ }^{241}$ The Constitution implicitly reserves to the federal government the power not only to enforce its laws but also to "execute its functions", 242 that power is inherent in the federal government qua government, and does not depend on express congressional authorization. ${ }^{243}$ Supremacy Clause immunity is simply a reflection of that power.

237. See id. at 1429 (emphasis added).

238. Id.

239. Cf. Gade v. Nat'l Solid Wastes Mgmt. Ass'n, 505 U.S. 88, 111 (1992) (Kennedy, J., concurring in part and concurring in the judgment) ("A freewheeling judicial inquiry into whether a state statute is in tension with federal objectives would undercut the principle that it is Congress rather than the courts that preempts state law.").

240. Clark, supra note 76, at 1453.

241. See supra notes $104-115$ and accompanying text; supra notes $172-180$ and accompanying text.

242. Ex parte Siebold, 100 U.S. 371, 395 (1879).

243. See McCulloch v. Maryland, 17 U.S. (4 Wheat.) 316,426 ("[A] power to create implies a power to preserve."). 
Still, one might object that there is a difference between cases in which state law will actually "retard, impede, burden, or in any matter control" a federal institution, ${ }^{244}$ and cases in which a federal officer faces state prosecution for conduct we now know to be beyond his authority. In McCulloch, for example, it was clear that the state tax would interfere with the functioning of the Bank. But in a case where a federal officer exceeds his authority and then successfully invokes immunity from state prosecution on the ground that his error was reasonable, state law is displaced based on a mistake. In this way, it might be argued, equating Supremacy Clause immunity with qualified immunity accords too much preemptive force to the mistaken judgments of individual federal officers.

We think this argument reads the federal interest at stake too narrowly. That interest is not just in keeping the letter of federal law free from state interference, but also in affording federal officers enough leeway to implement federal law and policy effectively. The integrity of federal law depends on its sound execution, which, in turn, depends on the actions of federal officers. Thus, as we have explained, ${ }^{245}$ the policy aim of qualified immunity-protecting against the "risk that fear of personal ... liability and harassing litigation will unduly inhibit officials in the discharge of their duties"246 - also describes the federal interest at stake in Supremacy Clause immunity.

The argument may also overstate the state interest at stake in Supremacy Clause immunity cases. Unlike typical statutory preemption, Supremacy Clause immunity does not displace state law in any categorical way. Rather, it merely limits the application of state law against a discrete, numerically limited set of potential defendants-federal officers. Moreover, in contrast to preemption cases involving areas of traditional state concern, shielding federal officers from state criminal law does not implicate a power reserved to the States at the Founding. The Constitution divides federal and state power so that, "[w]hile [the federal government] is limited in the number of its powers, so far as its sovereignty extends it is supreme. No State government can exclude it from the exercise of any authority conferred upon it by the Constitution [or] obstruct its authorized officers against its will ...."247 The Constitution surely reserved the general police power to the States, but it did not confer the authority to exercise that power against the federal government. To the contrary, state attempts to regulate the federal government or its agents directly implicate core federal interests.

244. Id. at 436.

245. See supra Subsection III.B.3.

246. Anderson v. Creighton, 483 U.S. 635, 638 (1987).

247. Tennessee v. Davis, 100 U.S. 257, 263 (1880). 
The circumstances of Horiuchi itself illustrate the point. It is difficult to imagine a court concluding that federal law enforcement actions aimed at arresting an individual on a federal warrant arising out of federal firearms charges somehow constitute an impermissible intrusion into areas of traditional state concern. In contrast, the federal interest in such a case is perfectly clear. At most, then, cases like Horiuchi arise in areas of overlapping state and federal concern. And although criminal law is surely an area of core state concern as a general matter, that does not change the operation of the Supremacy Clause in cases where state and federal interests conflict. ${ }^{248}$

\section{SUPREMACY CLAUSE IMMUNITY AND CONGRESSIONAL CHOICE}

As we have noted, most Supremacy Clause immunity cases arise in areas in which Congress has given no clear guidance on the immunity issue. The question in such cases is what to infer from congressional silence. Precedents ranging from $\mathrm{McC}$ Culloch to Neagle provide the answer: State law does not apply if it would threaten to interfere with federal interests. More specifically, federal officers may not be subject to state criminal prosecution for conduct they reasonably believe to be necessary and proper to the discharge of their federal functions.

But what if Congress does address the matter directly? In the main, we think that the extent of a federal officer's immunity from state law is a matter of congressional choice. Thus, for example, we think Congress probably could expose federal officers to the full force of state law by requiring that they comply with state law at all times. If Congress passed such legislation, federal officers facing state criminal prosecution would still have a due process right to fair warning, but there would be no trumping federal law for them to rely on and thus their fair warning right would have no Supremacy Clause aspect to it. Rather, they would be in the same position as all other criminal defendants subject to the law in question, entitled only to sufficient constructive notice that their conduct violated the law. Similarly, there would be no conflict between federal and state law, so implied conflict preemption would play no role.

One might insist, however, that the Constitution imposes some limits on Congress's power in this regard. Specifically, it might be argued that legislation expressly subjecting federal officers to strict liability under state criminal law would impermissibly intrude upon the constitutional

248. See Free v. Bland, 369 U.S. 663, 666 (1962) ("The relative importance to the State of its own law is not material when there is a conflict with a valid federal law, for the Framers of our Constitution provided that the federal law must prevail."). 
responsibilities and prerogatives of the executive branch. As the Neagle Court observed, the President's duty to "take Care that the Laws be faithfully executed" ${ }^{249}$ entails a certain measure of implied, discretionary power to take measures necessary to ensure the effective implementation of federal law. ${ }^{250}$ Arguably, Congress would intrude on that power by subjecting federal officers to the full force of state criminal law.

There are some substantive areas in which this objection seems sound. Where the executive branch has power to act even in the absence of legislative authorization - with respect to the military, for example ${ }^{251}$-we agree that the Constitution contemplates a certain latitude for executive action upon which Congress may not intrude. ${ }^{252}$ In such areas, Congress arguably transgresses the separation of powers if, in subjecting federal officers to the full constraints of state criminal law, it burdens the President's prerogatives as Commander in Chief.

Outside such specialized areas, however, the idea that the President's "take Care" authority entails an inalterable measure of officer immunity is less persuasive. To be sure, it would be unfair to require a federal officer to undertake a certain course of conduct as part of his job and then to subject him to state criminal prosecution for that conduct. But officers would not be put in such binds under the kind of federal statute we are hypothesizing. If Congress were expressly to provide that a federal officer is subject to state criminal law when discharging his federal duties, then he would lack the federal authority to engage in acts that violate state law. Even if conduct $x$ would otherwise fall within the scope of his federal authority, if it violated state law it would ipso facto be beyond his federal authority. He would not, then, be required by federal law to engage in the conduct. This standard need not amount to an intolerable burden on the federal officer, because (outside special areas like the military) he would have no obligation or authority to act except to effectuate federal law, ${ }^{253}$ and here federal law would incorporate state law. We are therefore inclined to think that in most areas, Congress probably could make federal officers subject to the full scope of state law when discharging their federal duties.

Now consider congressional choices at the opposite end of the spectrum. Could Congress make federal officers absolutely immune from

249. U.S. CONST. art. II, $\S 3$.

250. See In re Neagle, 135 U.S. 1, 64-66 (1889).

251. U.S. CONST. art. II, $\S 2$, cl. 1 .

252. Measuring such latitude is far beyond the scope of this Article, but we note Justice Jackson's observation that " $[w]$ hen the President takes measures incompatible with the expressed or implied will of Congress, his power is at its lowest ebb, for then he can rely only upon his own constitutional powers minus any constitutional powers of Congress over the matter." Youngstown Sheet \& Tube Co. v. Sawyer, 343 U.S. 579, 637 (1952) (Jackson, J., concurring).

253. See, e.g., Myers v. United States, 272 U.S. 52, 177 (1926) (Holmes, J., dissenting) ("The duty of the President to see that the laws be executed is a duty that does not go beyond the laws or require him to achieve more than Congress sees fit to leave within his power."). 
state prosecution for conduct taken under color of their office? Here too, we think the answer is probably yes. If Congress is competent to legislate in a given area in the first place-if, for example, the creation of a particular federal agency is a permissible exercise of Congress's enumerated powers - then it should follow that Congress can preempt the field by providing that the agency and its officers shall be subject only to the dictates of federal law.

Are there any limits here? Consider, for example, a statute that gives certain officers the authority to use deadly force, and that simultaneously provides that those officers may never be held to account under state law for their official actions. Then imagine a corrupt federal officer engaged in drug dealing, who uses his office to collect drug debts and eliminate rival drug dealers. May the federal statute immunize such lawlessness? Presumably not, but one needs to explain why with care.

There are at least two possible explanations. First, it might be argued that even though Congress is competent to legislate in a particular area (in our example, to create a federal agency charged with enforcing federal drug laws), the statutory provision conferring absolute immunity bears too little relation to the rest of the statute and to the constitutional head of legislative power Congress has exercised. Especially where a statute compromises a "traditional state function" like the police power, the Supreme Court has shown itself willing to impose rigorous limits on federal power. ${ }^{254}$

The conferral of absolute immunity, it might be argued, exceeds such limits. To the extent this argument amounts to an assertion that Congress may not provide absolute immunity for acts taken clearly within the scope of an officer's federal authority, we think it proves too much. If it is within Congress's power to legislate in a particular area and in so doing to create a federal agency charged with enforcing the law, ${ }^{255}$ then we think Congress can also define the body of law that governs the agency and its employees when acting in their official capacities. ${ }^{256}$ That is, we are skeptical that the

254. See United States v. Lopez, 514 U.S. 549, 577 (1995) (Kennedy, J., concurring) ("Were the Federal Government to take over the regulation of entire areas of traditional state concern, areas having nothing to do with the regulation of commercial activities, the boundaries between the spheres of federal and state authority would blur and political responsibility would become illusory.").

255. Of course, one possibility is that Congress actually lacks any authority to legislate in the relevant area. In that circumstance, obviously Congress would also lack the authority to immunize the officers charged with enforcing the unconstitutional enactment. Such officers might, however, be able to rely upon their due process right to fair waming as a shield against state prosecution at least until the law they are charged with enforcing is declared unconstitutional.

256. See Tennessee v. Davis, 100 U.S. 257, 263 (1880) ("No State government can exclude [the federal govemment] from the exercise of any authority conferred upon it by the Constitution [or] obstruct its authorized officers against its will ...."); McCulloch v. Maryland, 17 U.S. (4 Wheat.) 316, 436 (1819) (claiming that States may not "retard, impede, burden, or in any manner control, the operations of the constitutional laws enacted by congress to carry into execution the powers vested in the general government"). 
Constitution specially limits Congress's legislative authority when it comes to conferring officer immunity.

A more plausible justification for limiting officer immunity in this circumstance is that by any reasonable standard, the corrupt officer is clearly acting ultra vires and not within his official capacity. If the concern is with congressional immunization of rank lawlessness, the best response is that, to the extent an officer truly acts lawlessly, he acts so far beyond the parameters of his lawful authority that he is not acting in that respect as a federal officer. Just as federal judges otherwise entitled to absolute immunity may not claim immunity for nonjudicial acts or for acts totally outside their jurisdiction, ${ }^{257}$ federal law enforcement officers may not invoke the power of their office as a license to act so clearly outside the scope of, and unrelated to, their federal duties.

Within the broad limits we have suggested, we think Congress can dictate the scope of federal officers' immunity from state criminal prosecution. At bottom, Supremacy Clause immunity is concerned with resolving conflicts between state and federal law. By amending the reach of federal law, Congress can affect the extent of the conflict.

\section{THE SUPREMACY ClaUSE AND NATIONAL POWER}

The hierarchy of federal and state power established in the Supremacy Clause reflects the important constitutional principle that matters of truly national concern are the province of the national government. In Horiuchi, the national concern was with the ability of the FBI to carry out its law enforcement functions effectively and responsibly. In the absence of a contrary congressional instruction, those interests are best served, we believe, by granting federal officers immunity from state prosecution for conduct they reasonably believe to be necessary and proper to the discharge of their duties.

The larger point, however, is that it is ultimately for Congress to determine whether the national interest is served by such immunity doctrines, or whether it would better be served by, for example, exposing federal officers to the full sweep of state criminal law. Although Congress has not yet spoken to this precise question, it has addressed related issues in the areas of state tort law and state bar rules - granting expansive immunity

257. There are two circumstances in which otherwise absolute judicial immunity does not apply: "First, a judge is not immune from liability for nonjudicial actions, i.e., actions not taken in the judge's judicial capacity. ... Second, a judge is not immune for actions, though judicial in nature, taken in the complete absence of all jurisdiction." Mireles v. Waco, 502 U.S. 9, 11-12 (1991) (per curiam) (citations omitted); see also Forrester v. White, 484 U.S. 219, 227-29 (1988); Stump v. Sparkman, 435 U.S. 349, 356-57, 360-63 (1978). 
from the former and withholding all immunity from the latter. ${ }^{258}$ Respecting those divergent judgments accords with constitutional design. As the Court observed in McCulloch, Congress alone represents the Nation at large, and thus Congress is entrusted "with the power of controlling measures which concern all, in the confidence that it will not be abused." ${ }^{259}$ In short, it is for the federal government-and especially Congress-to decide the extent to which the States should play a role in matters of truly national concern.

To be sure, the Supreme Court has not always adopted this approach. Consider the Court's principal Tenth Amendment cases from the past decade its anticommandeering precedents, New York ${ }^{260}$ and Printz. ${ }^{261}$ These cases established independent federalism-based limits on federal power, even where it otherwise appeared clear that Congress possessed the Article I authority to pass the federal statute in issue. New York and Printz were criticized when they were announced for needlessly hampering the ability of the federal government to respond to important national problems. ${ }^{262}$ As Justice Stevens observed in his Printz dissent, the "threat of an international terrorist[] may require a national response before federal personnel can be made available to respond.,"263 "[I] s there anything [in the Constitution]," Justice Stevens asked, "that forbids the enlistment of state officers to make that response effective?"264

After September 11 th, Justice Stevens's dissent resonates all the more deeply, so much so that it is difficult to imagine the Court interposing federalism-based obstacles to the federal government's attempt to respond effectively and, at times, creatively, to homeland security and other problems of a national dimension. ${ }^{265}$ If so, this would be a salutary development. Where problems of truly national concern arise, the federal government is clearly better situated to determine the appropriate governmental response. If Congress concludes that a cooperative federalstate response is the best way to address the problem, there is little reason to infer from the Tenth Amendment an independent limit on such a determination. ${ }^{266}$

258. See supra Section III.C.

259. 17 U.S. (4 Wheat) at 431.

260. New York v. United States, 505 U.S. 144 (1992).

261. Printz v. United States, 521 U.S. 898 (1997).

262. See, e.g., Jackson, supra note 32.

263. S21 U.S. at 940 (Stevens, J., dissenting).

264. Id.

265. See Wendy E. Parmet, After September 11: Rethinking Public Health Federalism, 30 J.L. MED. \& ETHICS 201, 201 (2002) ("[S]uccessful public health interventions require an effective partnership between federal and state authorities. This requires a flexible and pragmatic understanding of the scope of federal authority."); $i d$. at 207-08 ("[W]hen the felt need has been great enough, the federal government has always assumed the power to respond. Pragmatism, flexibility, and realism have thus been the most enduring norms of federalism.").

266. Justice Breyer appeared to make this sort of point when, in a lecture delivered shortly after the shock of September 11 th, he counseled a new sensitivity to the importance of giving the 
Although Supremacy Clause immunity issues themselves tend to surface in times of heightened federal-state friction quite unlike the current era, related questions have arisen since September 11 th. Consider the recent litigation in New Jersey concerning so-called secret detainees. In March 2002, a judge on the New Jersey Superior Court held that state law obliged the federal government to disclose the names and detention dates of all aliens secretly held under federal authority in New Jersey state facilities. ${ }^{267}$ The judge reasoned that if the federal government wanted to use state facilities to detain people, it had to comply with state public-information law. That decision was reversed in June 2002 by the New Jersey Appellate Division. ${ }^{268}$ As the appellate court noted, five days after the trial court's decision, the Justice Department adopted as an interim rule a new regulation ${ }^{269}$ forbidding the public release of information about so-called Special Interest detainees without the express permission of the Immigration and Naturalization Service. ${ }^{270}$ That new regulation would be frustrated, the court found, if federal officials were forced to comply with New Jersey disclosure laws. ${ }^{271}$ The court rejected arguments that federal authority in this area ought to be construed narrowly in order to preserve a role for state law. ${ }^{272}$ And it further stressed that appeals to the State's traditional authority over the operation of its jails and other facilities did not alter the analysis. ${ }^{273}$ Whatever the State's authority as a general matter, the

federal government wide berth to respond to pressing problems of national concern in the wake of the terrorist attacks. See Stephen Breyer, Our Democratic Constitution, 77 N.Y.U. L. REV. 245 (2002) (reprinting Justice Breyer's 2001 Jarnes Madison lecture).

267. The Superior Court's decision is unpublished. For a discussion of the decision, however, see Press Release, American Civil Liberties Union, ACLU of New Jersey Wins Access to Information on Post-September 11 Detainees (Mar. 27, 2002), at http://archive.aclu.org/ news/2002/n032702a.html (describing ACLU v. County of Hudson, No. A-4100-01T5 (N.J. Super. Ct. Mar. 27, 2002)).

268. ACLU v. County of Hudson, 799 A.2d 629 (N.J. Super. Ct. App. Div. 2002). The New Jersey Supreme Court subsequently denied discretionary review of the appellate division's decision. ACLU v. County of Hudson, 803 A.2d 1162 (N.J. 2002).

269. 67 Fed. Reg. 19,508 (Apr. 22, 2002). The regulation provides, in pertinent part:

No person, including any state or local government entity or any privately operated detention facility, that houses, maintains, provides services to, or otherwise holds any detainee on behalf of the [INS] . . shall disclose or otherwise permit to be made public the name of, or other information relating to, such detainee. Such information shall be under the control of the [INS] and shall be subject to public disclosure only pursuant to the provisions of applicable federal laws, regulations and executive orders.

Id. at 19,511 .

270. County of Hudson, 799 A.2d at 638-39.

271. Id. at 650 .

272. Id. at 648-49 ("[W]e would breach faith with overarching principles of our federalism if we were to see this case as an occasion for viewing the grant of authority to the [INS] Commissioner as anything but very broad.").

273. Id. at 654 ("[W]hile the State possesses sovereign authority over the operation of its jails, it may not operate them, in respect of INS detainees, in any way that derogates the federal government's exclusive and expressed interest in regulating aliens."). 
attempt to apply state disclosure laws against the federal government in that case implicated and conflicted with clear federal interests and regulations, and neither the Tenth Amendment nor any other constitutional provision preserves a role for state law in such circumstances.

The New Jersey case became easy once the Justice Department adopted the new regulation restricting the disclosure of detainee information. The State's public disclosure requirements conflicted directly with the express provisions of the new federal regulation; standard preemption principles dictated the outcome. Absent the new regulation, however, the case presented a difficult question. On one hand, the federal government clearly has a strong interest in controlling the public disclosure of information about its "Special Interest detainees," and the imposition of state publicdisclosure requirements could easily undermine that interest. On the other hand, the detention facilities belonged to New Jersey, and the federal government need not have used those facilities if it objected to the state laws governing them. Indeed, to the extent the federal government wished to use the facilities, one might argue that the State should have been able to impose conditions on their use in roughly the same way that the federal government can condition a State's receipt of federal funds. ${ }^{274}$

Of course, the New Jersey case does not involve questions of officer immunity. Rather, the case requires determining the proper state-federal balance directly, unmediated by considerations of immunity, fair warning, and the like. Striking that balance would have been difficult in the absence of the intervening Justice Department regulation, and we are not prepared to say how the case should have been resolved in that circumstance. We are persuaded, however, that as a matter of analytical method, courts should avoid categorical judgments about the division of state and federal power, and should instead be attentive to the extent of actual conflict between state law and federal functions. McCulloch, not Printz, provides the model.

\section{CONCLUSION}

As a limitation on the power of the national government, federalism functions primarily through the concept of enumerated powers. The Tenth Amendment confirms this point and "directs us to determine ... whether an incident of state sovereignty is protected by a limitation on an Article I power. ${ }^{275}$ But once we are confident that the federal government is competent to act in a certain area, federalism properly imposes few judicially enforceable barriers to that action. Rather, we generally defer to

274. See, e.g., South Dakota v. Dole, 483 U.S. 203 (1987).

275. New York v. United States, 505 U.S. 144, 157 (1992). 
Congress's judgment about how best to reconcile overlapping federal and state power in areas where both are legitimately exercised.

This is especially true with respect to a State's ability to constrain the conduct of federal law enforcement officers like Agent Horiuchi. Even in the midst of a rising tide of States' rights at the Supreme Court, it seems extremely unlikely that the Court will hold that the laws creating a federal agency like the FBI exceed Congress's legislative authority. But once that point is conceded-once we acknowledge, in cases like Horiuchi, that the creation of the FBI is a legitimate exercise of congressional power-the role of federalism in this area properly becomes quite modest. Rather, the governing constitutional rule is simply that of the Supremacy Clause itself, under which federal law is supreme and the only real question is how the federal government has chosen to express that supremacy. 
$* * *$

Imaged with the Permission of Yale Law Journal 